
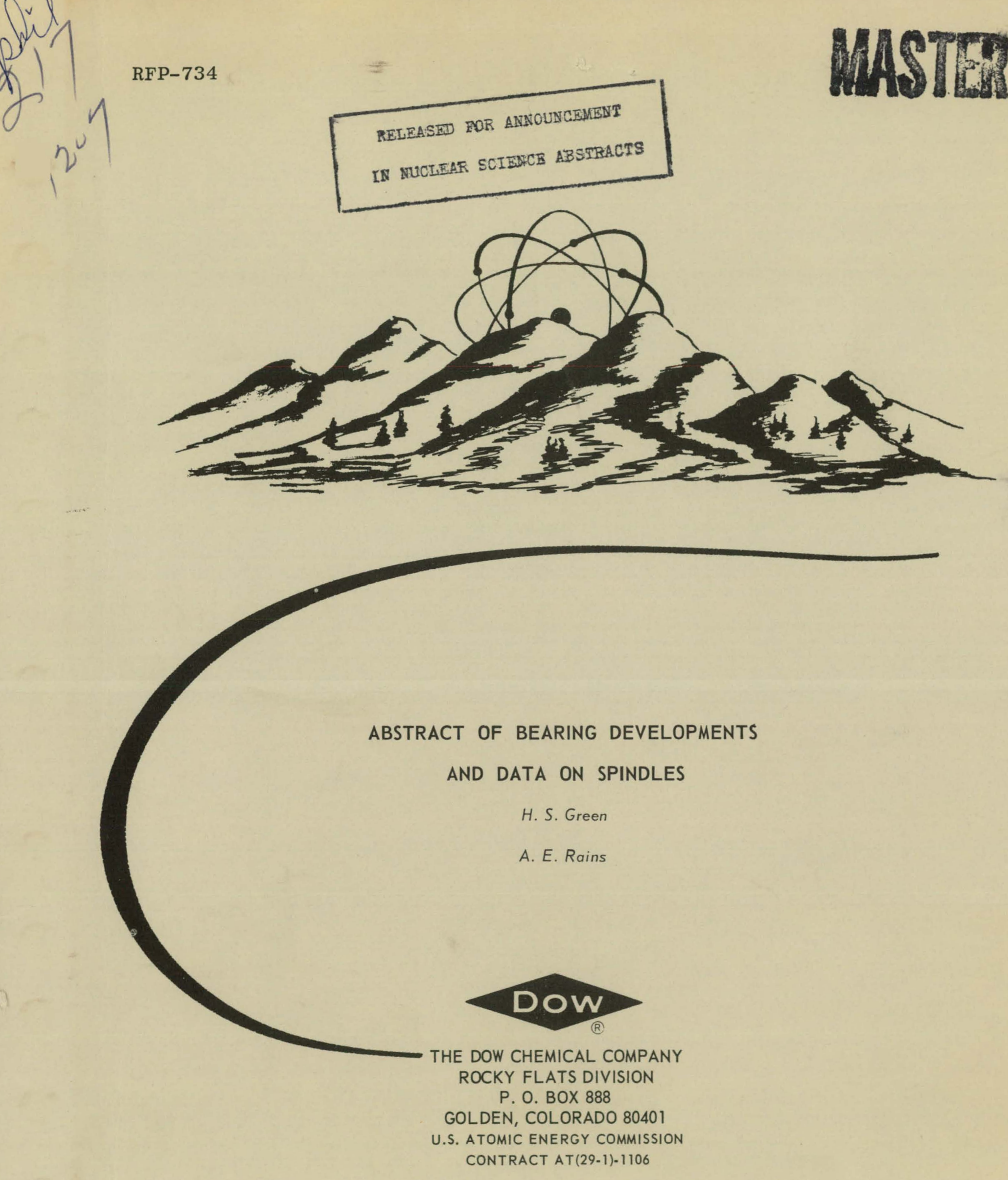


\section{DISCLAIMER}

This report was prepared as an account of work sponsored by an agency of the United States Government. Neither the United States Government nor any agency Thereof, nor any of their employees, makes any warranty, express or implied, or assumes any legal liability or responsibility for the accuracy, completeness, or usefulness of any information, apparatus, product, or process disclosed, or represents that its use would not infringe privately owned rights. Reference herein to any specific commercial product, process, or service by trade name, trademark, manufacturer, or otherwise does not necessarily constitute or imply its endorsement, recommendation, or favoring by the United States Government or any agency thereof. The views and opinions of authors expressed herein do not necessarily state or reflect those of the United States Government or any agency thereof. 


\section{DISCLAIMER}

Portions of this document may be illegible in electronic image products. Images are produced from the best available original document. 


\section{LEGAL NOTICE}

This report was prepared as an account of Government sponsored work. Neither the United States, nor the Commission, nor any person acting on behalf of the Commission:

A. Makes any warranty or representation, expressed or implied, with respect to the accuracy, completeness, or usefulness of the information contained in this report, or that the use of any information, apparatus, method, or process disclosed in this report may not infringe privately owned rights; or

B. Assumes any liabilities with respect to the use of, or for damages resulting from the use of any information, apparatus, method, or process disclosed in this report.

As used in the above, "person acting on behalf of the Commission" includes any employee or contractor of the Commission, or employee of such contractor, to the extent that such employee or contractor of the Commission, or employee of such contractor prepares, disseminates, or provides access to, any information pursuant to his employment or contract with the Commission, or his employment with such contractor.

Printed in USA. Price $\$ 2$. Available from the Clearinghouse for Federal Scientific and Technical Information, National Bureau of Standards,

U. S. Department of Commerce, Springfield, Virginia 22151 
RFP-734

4 November 1966

UC-38 ENGINEERING

AND EQUIPMENT

TID- 4500

CoNf- $660922-2$

RELEASED. FOK ANNOUNCEMENT

IN NUCLEAR SCIENCE ABSTEACTS

II.c. $9.00 ;$.

\title{
ABSTRACT OF BEARING DEVELOPMENTS AND DATA ON SPINDLES
}

\author{
H. S. Green \\ A. É. Káins
}

Address delivered at the Seventh International Machine

Tool Design and Research Conference

University of Birmingham

Birmingham, England

September 12-16, 1966

THE DOW CHEMICAL COMPANY

ROCKY FLATS DIVISION

P. O. BOX 888

GOLDEN, COLORADO 80401

U.S. ATOMIC ENERGY COMMISSION

CONTRACT AT(29-1)-1106

\section{LEGAL NOTICE}

This report was preparta an account or

A. Makes any warranty, nor any person acting on behnif racy. completeness, or usty or representation, expressed or of the Commission:

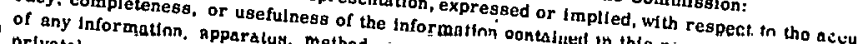

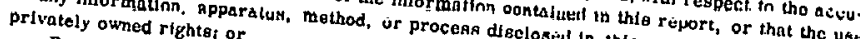

B. Assumes rights; or

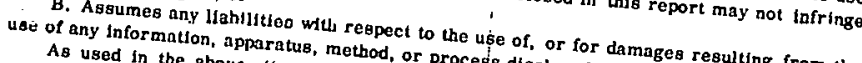

As used in the above, "pers method, or process disclosed damages resul

ployee or contractor of the corson acting on behalf of the coed in this report.

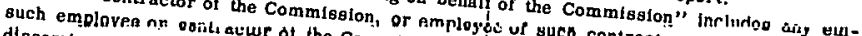

disseminates, or provides act of the Commlssion, or employes contractor, to the extent the

with the Commisston, or access to, any Information pursyee of such contractor preparat

the Commisston, or his employment with such pursuant to hls employment prepares, 


\section{ABSTRACT OF BEARING DEVELOPMENTS AND DATA ON SPINDLES}

Introduction

Past revolutionary developments of bearings since the late 18th Century will not be summarized in considerable detail, as. many descriptive and complete books have been written on bearing technology history. ${ }^{1}$. Briefly, however, some developments since the early 19th Century will be noted. An interesting historical reference is that the Chinese guarded their secret of bearings use for centuries, yet no records or evidence of bearings have been preserved for study.

Credit for modern anti-friction bearings goes to the engineering genius of the Renaissance, Leonardo da Vinci, for his inventions making use of such bearings in wagon wheels about A.D. 1500. In earlier periods, wooden rollers were used.

Before the 20th Century, the use of balls and races were common in bicycles. Cast-iron and steel balls were made and patented in both England and America between 1860 and 1895 . Before balls could be made with any accuracy however, roller bearings were in use.

Often referred to as the father of the ball and ballbearing industry is the son of Philipp Moritz Fischer, Friedrich Fisher (1848-1899). He built the first bicycle with pedals and invented the ball mill.

Within this period, another related development took place in German industry. ${ }^{2}$ About 1890, for example, the cleveland Machine Screw Company of Cleveland, Ohio, designed and built

\footnotetext{
${ }^{1}$ Hudson T. Morton, "Anti-Friction Bearings." Second Edition. Published by the author, 1606 Morton Avenue, Ann Arbor, Michigan. 1965. 514 pages.

2 Ibid. Page 445.
} 
equipment used in its original steel-ball plant for the Deutsche Waffen and Munitions Fabriken of Berlin, Germany. This marked an important step for the industry and as a consequence the DWMF later acquired a reputation for making high grade balls. The "DWF" trademark now used, identifies the company as a member of the international sales organization, the Svenska Kullagerfabrieken (SKF). ${ }^{3}$

The shipment of equipment to Germany was done on a mutual exchange basis, with no manufacturing rights involved. Without question the cleveland company can be lauded for bringing American ingenuity to other shores with due credit for successful application by German industrialists. Many countries have been involved nevertheless in the overall technological advances to date.

In the year 1900, one of the oldest machine tool builders in America designed a combination sleeve and ball-bearing spindle. The questions pondered are what motivated the design and what were the needs. Currently from what is now available, the problem would be much simpler but for that particular period, a need existed for grinding accurately to size, such items as die pins, bearing races, and bushings after they had been heattreated.

It would be worth noting that the use of tapered sleeve bearings prevailed until 1919, and grinding accurately to obtain good surface finishes varied from hour to hour and day to day. One of the earlier spindles used in 1919 is illustrated in Figure 1. Much depended upon the ability of the machinist to maintain the spindle adjustments and the fit of the sleeve bearing. As a result, considerable time was lost refitting and rescraping bearing surfaces.

These problems motivated other machine tool builders to. design ball-bearing, grinding spindles so that by 1925 many such bearings were in use. These spindles were run at speeds that varied from $12,000 \mathrm{rpm}$ to $35,000 \mathrm{rpm}$. Such high speeds

\footnotetext{
$\overline{3 \text { Ibid. Page } 485 .}$
} 


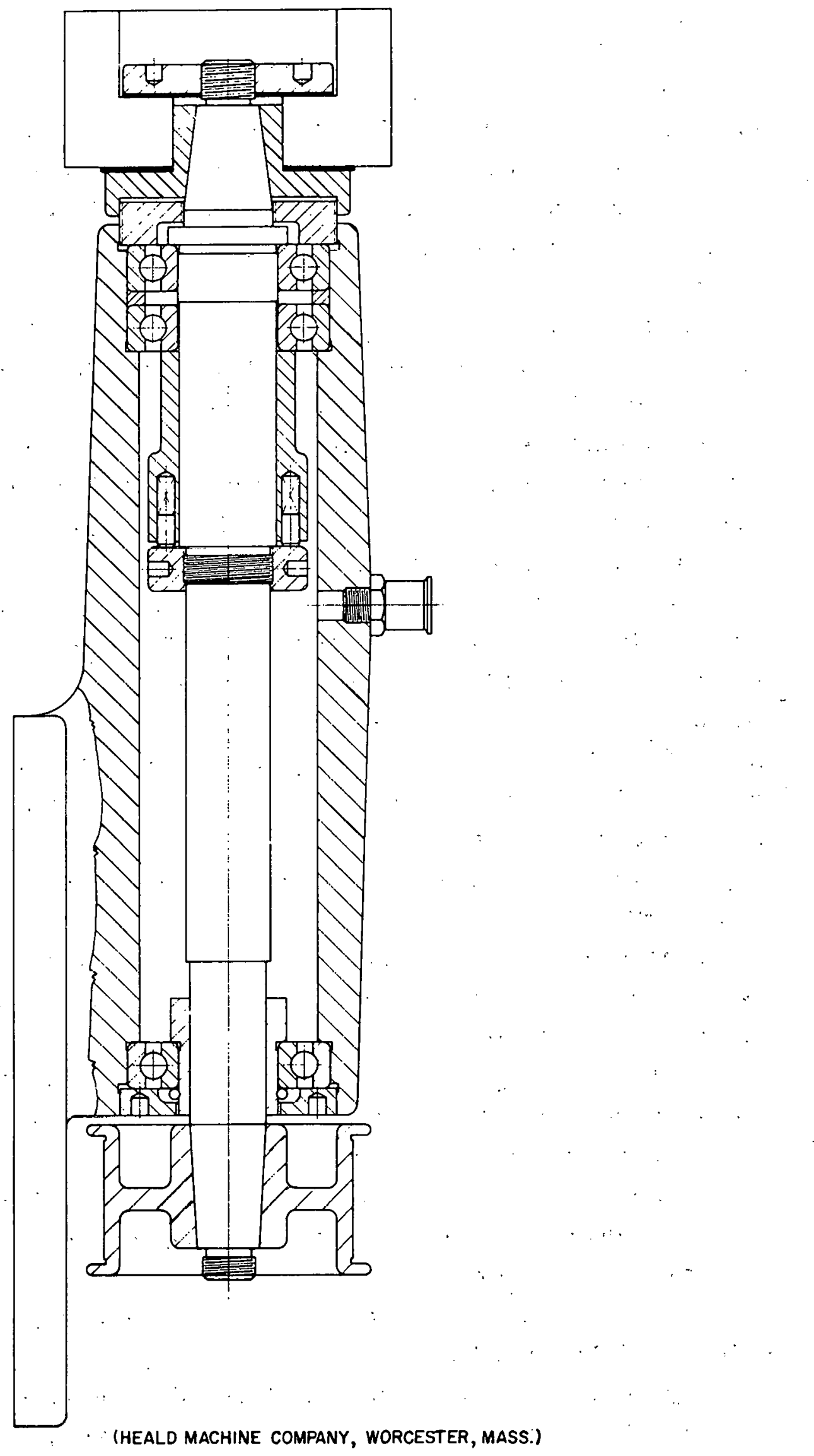

FIGURE I. DESIGN OF BALL BEARING SPINDLE USED IN 1919 
could be attained by the use of air motors.

By 1926, a spindle was introduced that could be run at speeds of $65,000 \mathrm{rpm}$. The air motor drive consumed 15 cubic feet of air per minute at 90 psi pressure, using the exhaust air to cool the bearings. Thus, bearings in use today came from efforts to meet early imperative needs for good grinding processes.

During 1928, the grinding spindle. came into use for boring applications. The automotive industry provided the motivation; it needed a better way to bore connecting rods. The lack of cemented carbides however held back much of the progress anticipated. There were many failures in designs because of the emphasis placed on boring metals at high speeds in order to obtain good finishes. Such was the theory then.

Later, the staygered-uall princtple came into the picture for use in boring applications. By 1930, some of the best machine tool builders of the nation were producing precision boring machines. These became referred to as precision machine tools by 1932. Since cemented carbides in different grades were developed about this time also, the boring machine could be used on cast iron and steel.

Following this period, developments were rapid, even advancing into other related fields. Thread grinders, lathes, large boring mills, multiple-cluster boring, jig mills, jig borers, etc., are now well known by the trade, along with various applications.

Before continuing, a review of two definitions is suggested. One is taken from Webster's Third New International, 1961 , unabridged, which reads:

Bearing: an object, surface, or point that supports; or a machine in which a journal, gudgeon, pivot, pin or other part turns.

In one of the machine tool handbooks used, the definition refers to the spindle as:

Spindle: long, round slender rod, one which turns or on which something turns; an arbor, mandrel, axle or shaft, such as the line spindle of a lathe that imparts motion 
to the work. A revolving piece less in size than a shaft.

The term spindle has been accepted for general use in describing that part of a machine imparting motion to the work done. Reference to the bearings as a compliment of the spindle has been in use as well, so there should be no confusion with these terms.

It may also be helpful to insert some reference to the bearing here. A ball or sphere has often been called a "bearing" because objects rotate around it or move on rotating elements.

Design

The earlier ball bearings in use during 1900 were singlerow, four-point contact bearings; two contacts on the outer race and two contacts on the inner race (Figure 2). The whole bearing consisted of a ball retainer, an inner race, an outer race, balls, and an outside retaining ring: Construction of the whole bearing as described was employed generally by manufacturers as late as 1920. Many of these bearings however were noisy because retaining rings as known today differed considerably from the crude ones of earlier times. A few years later, other methods for driving these spindles came into use, as air turbin motors, combined wi.th the spindle. Again, the noise problem was a prime one.

The single-row, four-point contact bearing was discarded by most manufacturers in 1924 in lieu of a double-row; three-point contact bearing (Figure 3). Still the problem existed with ball retainers as a source of noise and roughness until introduction was made of bakelite and impregnated fiber materials for retainers.

During 1927-28, the design and use of ball bearings for boring operations were wrought with many trials and errors; the general approach being that an odd number of balls would give smoother finishes. The stagger-ball design came about during trials of having one ball under load at all times.

With new design of retainers for the balls and a sealing of the bearings to retain oil and grease for prevention of grit and dirt accumulations, the life of the bearing has been prolonged (Figure 4). In many applications f.earings are sealed within housings thereby making it possible to pump filtered oil directly into the bearings. 


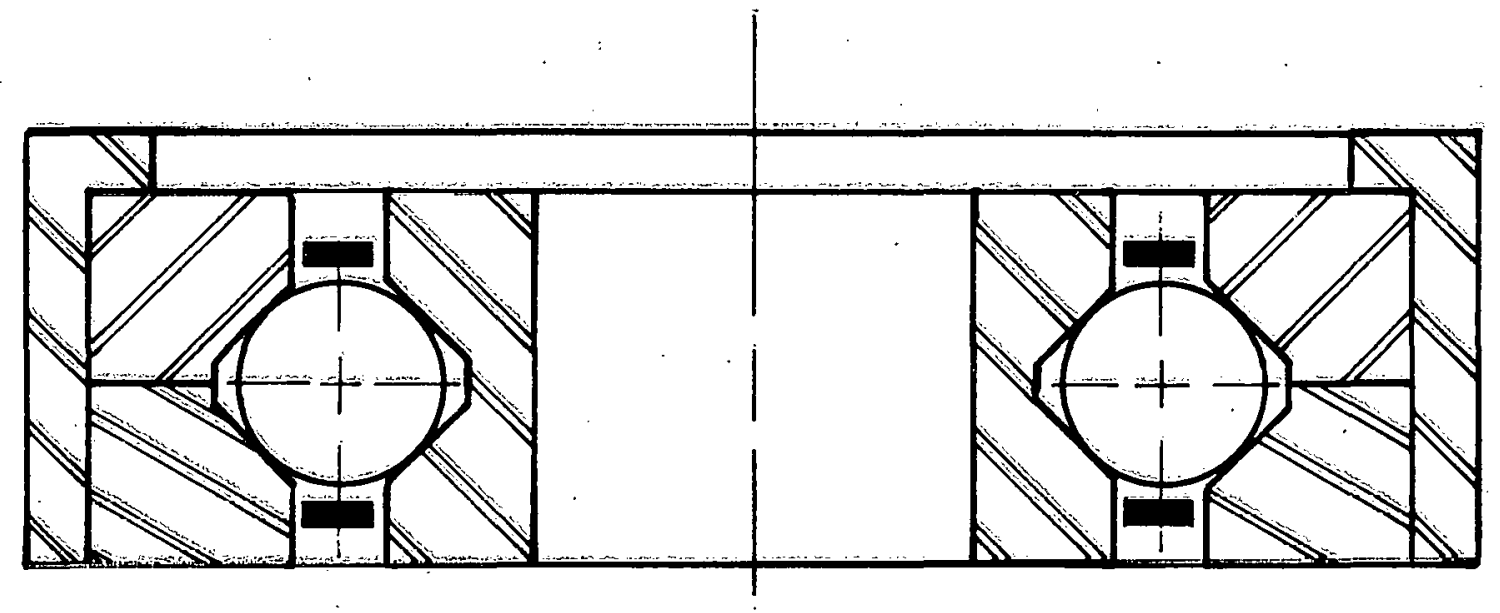

FIGURE 2. SINGLE ROW, FOUR POOINT CONTACT BALL BEEARING 


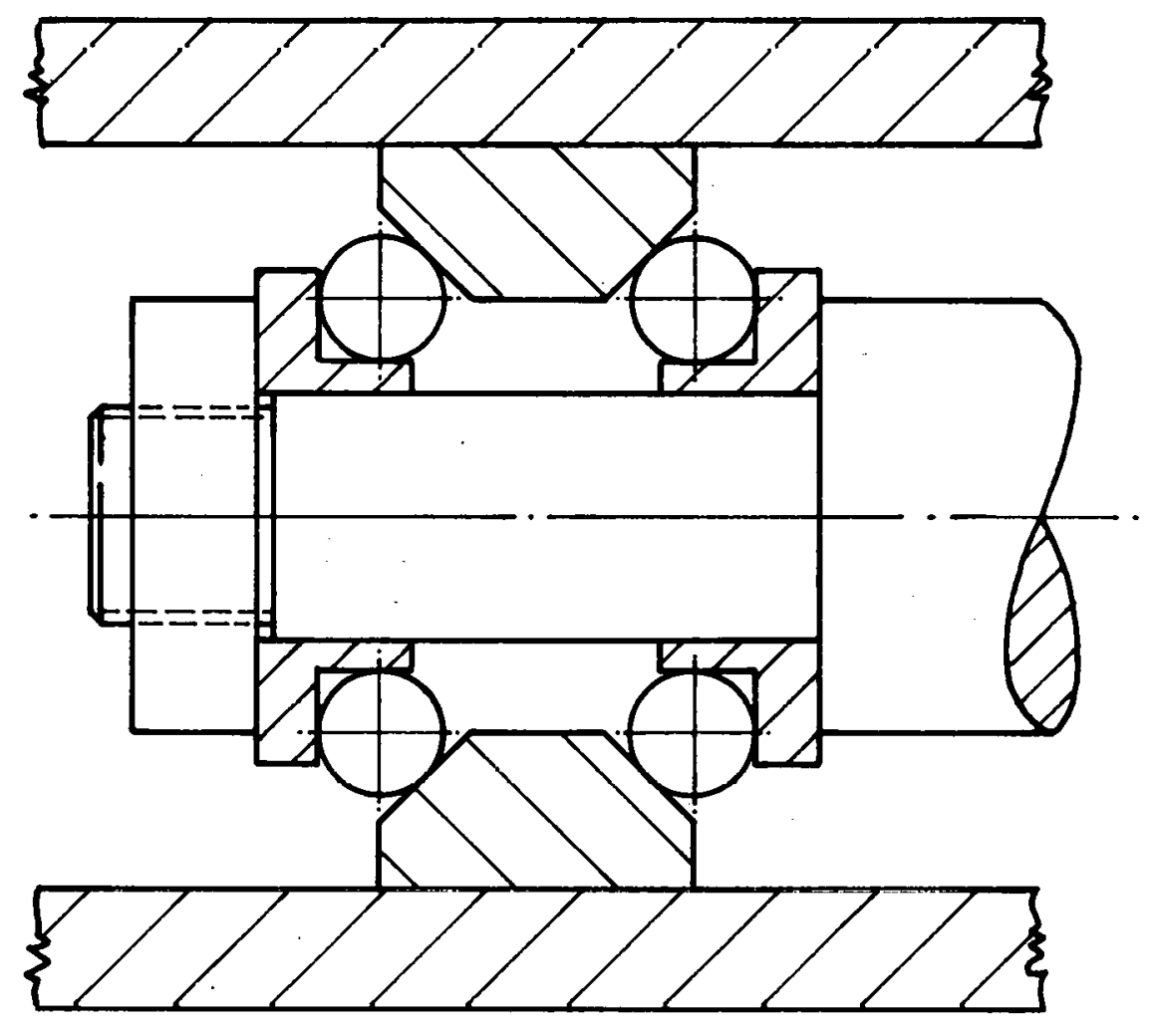

FIGURE 3. DOUBLE ROW, THREE POINT CONTACT BALL BEARING 


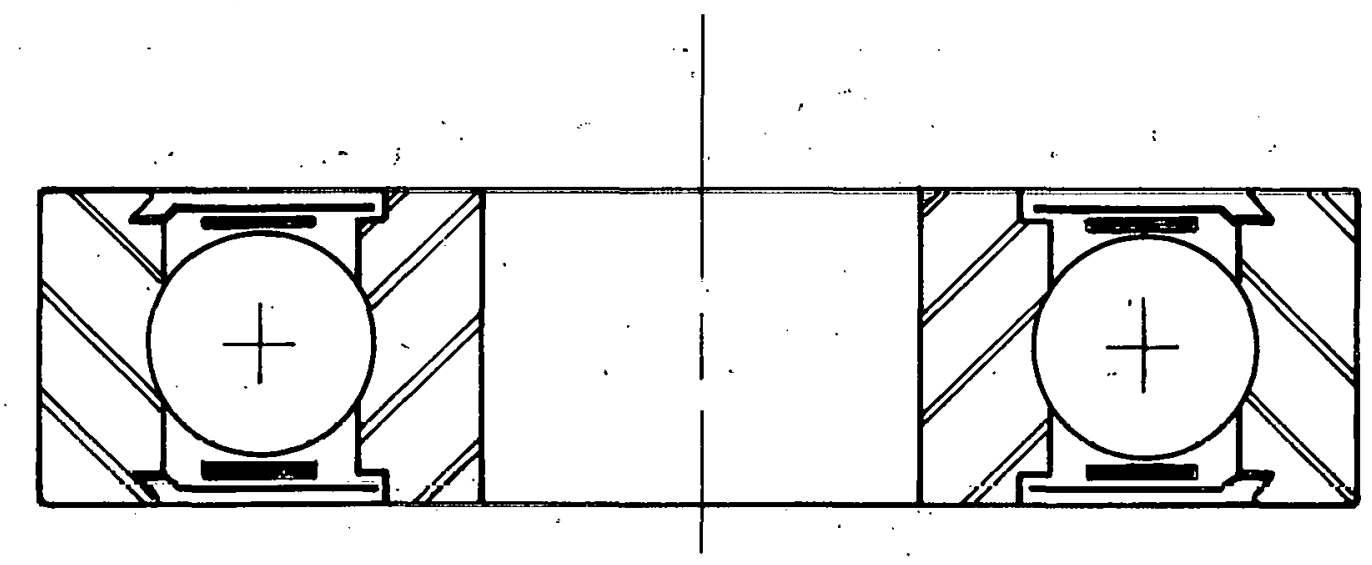

FIGURE 4. 'THE`MODERN BALL BEARING 
Scientific studies have been conducted to determine why a ball and race suddenly start to deteriorate and flake. Such studies as of this date have concentrated on the forging process. The flow of the forged metal seems to have some relation to where the point of breakdown occurs in balls and races. This has been proven by positioning the flash line which is identified on a ball as the equator. The line is made by drilling a small hole in the ball before it is ground and finished to size.

The race is identified with the forged billet, and samples are cut from the billet as right-angle sections and two others $45^{\circ}$ from both sides of the right-angle cut. The bearing components are fabricated and assembled in the normal way, except each one is identified as to its position from the section of the forging. These bearings are set up in a test frame and run until excessive noise is electronically recorded, thereby indicating a breakdown. They are then disassembled and studied, noticing especially the points of flaking in relation to the reference points.

An interesting finding from recent tests indicates that the flow lines which converge during forging and lines parallel to the surface have breakdowns of greater frequency than at other locations. It has been also observed that forging temperatures are very critical, and control must be exercised within a high degree of accuracy to obtain meaningful results.

Some of the more exotic methods of testing bearings are those done by the National Aeronautics and Space Administration ${ }^{4}$ such as with nonconventional solid lubricants (indium, thallium, lead, tin cadmium, gold, silver, platinum, rhodium, graphite, and molybdenum disulphide). Solid lubricants having good thermal and oxidative stability are considered suitable for high temperature use. In such tests, temperatures normally reach as high as $788^{\circ} \mathrm{C}$.

${ }^{4}$ E. E. Bisson and W. J. Anderson. "Advanced Bearing Technology." NASA SP-38. National Aeronautics and Space Administration, Washington, D. C. 1964. Pages 203=255. 
Other lubricants are being used also and the NASA reference gives data on these and other studies being conducted on anti-friction bearings. These studies are important particularly in space research where many unusual conditions exist of which we have no knowledge as compared to conditions known on earth where normal gravitation and atmosphere controls life.

Spindle Bearing Types

Much can be said regarding spindle and bearing accuracy. In listing specifications, desired accuracies in a bearing may be given during purchase or random selection made of an offthe-shelf item. Perhaps a lathe recently purchased was accepted on its face value, with a possible restriction rcgarding the spindle end growth. My inference is that if we desire a special spindle we buy it with a specific purpose in mind, perhaps for use as a retrofit or in a special gaging problem, or even a complete gage. If we are willing to spend the money and time to select, we can obtain a spindle with the most exotic tolerance. Even so, considerable patience and skill is required to obtain the necessary accuracy.

Most off-the-shelf spindles will be quoted with an accuracy from 50 to 80 millionths of an inch and with a few exceptions, this may satisfy general needs. In the market today, there are being introduced many new concepts of bearing and spindle accuracy. Thus, it is desirable to illustrate current hearing: specitications and types, and what kinds are expected to be available in the near future:

In Figure 5, comparisons are given of the different types of bearings which can be used to compliment the spindle. It should be noted that the proper selection of bearings to fit the type of work done, as well as accuracy and durability, are all very important. There are advantages and disadvantages however to be considered by good engineering and practical experience. Figure 6 (a, b, c, d, e and $f$ ) and Figure 7 ( $g, h, i, j, k$ and l) show diagramatically the various subtypes, then attempts to compare selected characteristics common to all. It is not meant to be all-inclusive in listing either types or characteristics, 
FIGURE 5. DATA CHART FOR VAFIOUS BEARING TYPES

\begin{tabular}{|c|c|c|c|c|c|c|c|c|c|c|c|c|c|c|c|}
\hline 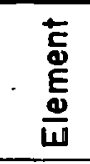 & & $\begin{array}{r}\text { Type } \\
\text { and } \\
\text { infigura }\end{array}$ & & $\left|\begin{array}{l}\text { Rodial } \\
\text { Accuracy }\end{array}\right|$ & $\begin{array}{l}\text { First } \\
\text { Cost }\end{array}$ & Maint. & Life & Space & Ad just. & $\begin{array}{c}\text { O'r load } \\
\text { Cop. }\end{array}$ & $\begin{array}{r}\text { Heat } \\
\text { Gen. }\end{array}$ & Friction & $\begin{array}{l}\text { Ambient } \\
\text { Effects }\end{array}$ & "Pickup" & Rating \\
\hline \multirow{6}{*}{$\frac{E}{\bar{L}}$} & \multirow{4}{*}{ 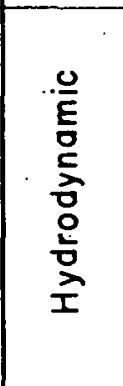 } & \multirow{3}{*}{ Fixed } & $\begin{array}{c}\text { Cyl. } \\
\text { Journal }\end{array}$ & 1 & 1 & 2 & 3 & 1 & 3 & 3 & 2 & 3 & 2 & 3 & \\
\hline & & & \begin{tabular}{|l|} 
Taper \\
Journal
\end{tabular} & 1 & 1 & 2 & 3 & 2 & 2 & 3 & 2 & 3 & 2 & 3 & \\
\hline & & & $\begin{array}{r}\text { Pumping } \\
\text { Journal }\end{array}$ & 2 & 3 & 3 & 1 & 1 & 3 & 3 & 3 & 1 & 3 & 2 & \\
\hline & & Var. & Kingsbury & 1 & 2 & 3 & 3 & 3 & 3 & 2 & 3 & 3 & 2 & 3 & \\
\hline & \multirow{2}{*}{ 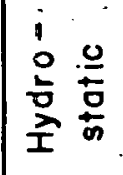 } & Liquid & & 3 & 3 & 3 & 1 & 3 & 2 & 1 & 1 & 1 & 3 & 2 & \\
\hline & & Gas & & 3 & 3 & 3 & 1 & 3 & 2 & 1 & 1 & 1 & 2 & 2 & \\
\hline \multirow{8}{*}{ 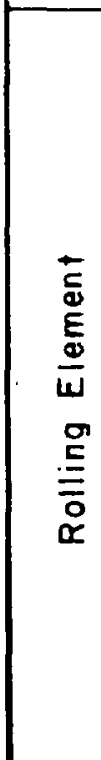 } & \multirow{6}{*}{$\therefore \frac{\bar{a}}{\overline{\bar{c}}}$} & \multirow{3}{*}{ Cyl. } & $\begin{array}{r}\text { 3-piece } \\
\text { Solid }\end{array}$ & 2 & 2 & 2 & 2 & 2 & 3 & 2 & 2 & 2 & 1 & 1 & \\
\hline & & & $\begin{array}{l}\text { 3-piece } \\
\text { Wound }\end{array}$ & 1 & 2 & .1 & 2 & 2 & 3 & 1 & 3 & 3 & 1 & 2 & \\
\hline & & & $\begin{array}{l}\text { 2-piece } \\
\text { Needle }\end{array}$ & 3 & 2 & 2 & 2 & 1 & 3 & 2 & 2 & 2 & 1 & $\cdot 1$ & \\
\hline & & Taper & & 2 & 2 & 2 & 2 & 2 & 2 & 2 & 2 & 2 & 1 & 1 & \\
\hline & & \multirow{2}{*}{ Sph. } & Barrel & 2 & 2 & 2 & 2 & 2 & 2 & 2 & 2 & 2 & 1 & 1 & \\
\hline & & & Shafer & 2 & 2 & 2 & 2 & 2 & 2 & 2 & $2^{\prime}$ & 2 & 1 & 1 & \\
\hline & \multirow{2}{*}{$\overline{\bar{a}}$} & Rad. & & 3 & 1 & 1 & 2 & 2 & 2 & 3 & 1 & 1 & -1. & $!$ & \\
\hline & & Ang. & & 2 & 1 & $!$ & 2 & 2 & 2 & 3 & 1 & 1 & $\cdots 1$ & 1 & \\
\hline
\end{tabular}




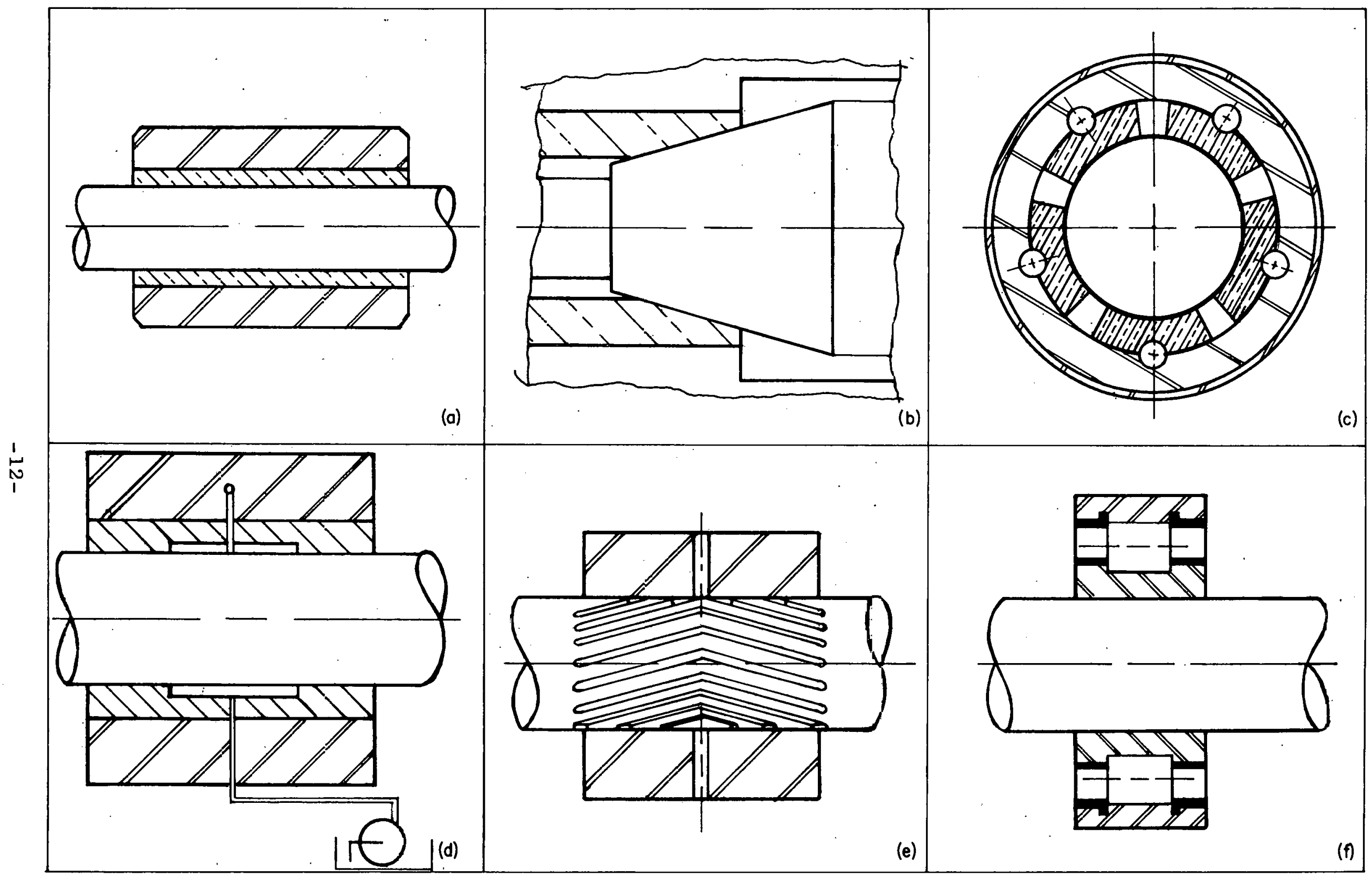

FIGURE 6. BEARING TYPES LISTED IN FIGURE 5: (a) CYLINDRICAL JOLRNAL, (b) TAPERED JOURNAL, (c) KINGSBURY, (d) HYDROSTATIC, (e) PUMPING JOURNAL, AND (f) THREE-PIECE SOLID ROLLER 


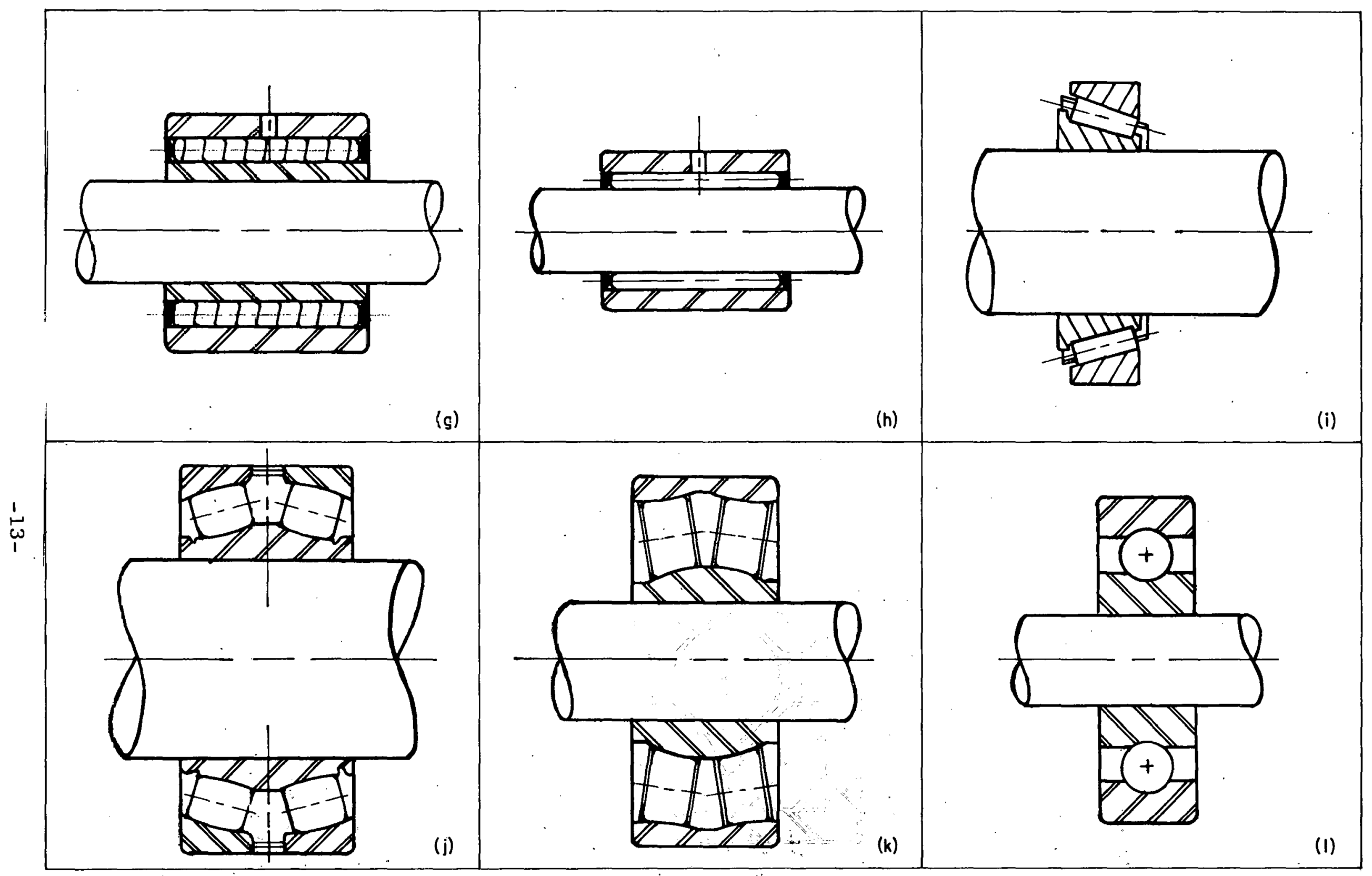

FIGURE 7. BEARING TYPES LISTED IN FIGURE 5: ( $g$ ) THREE-PIECE WOUND ROLLR, (h).TWO-PIECE NEEDLE, (i) TAPERED ROLLER, (j) BARREL ROLLER, (k) SHAFER ROLLER, AND (1) RADIAL CONTACT 
but rather to furnish an overall general view of the current bearing situation. Certain conclusions about bearings can be drawn from the chart and these will follow later.

Classification Terminology

Terminology used in bearing classification is largely selfexplanatory, but certain points are worth noting.

"Element" refers to the means by which friction is overcome in the bearing. There are other elements (magnetic and electrostatic fields, dryfilm lubrication, etc.), but they are out of place in a discussion of machine tool spindles.

"Pumping Journal" refers to a type of bearing in which grooves or patterns of grooves in the journal "pump-up" a lubricating fluid by virtue of the journal's rotation. Generally referred to as an "enhanced" hydrodynamic bearing, it may be supplemented by external pressurization where low start-up friction or high loads are involved.

"Variable" and "Kingsbury" refer to a type of hearing in which the journal is supported by several pivoted "shoes." These shoes adjust their angle automatically with load and speed to maintain the most desirable fluid-film wedge angle. Usually found on large spindles, this bearing is now being replaced by roller or hydrostatic bearings.

"Radial" and "Angular" refer to the mode of contact between the balls and races of a ball bearing. Angular contact bearings will support axial as well as radial loads, whereas radial contact bearings. do not.

Characteristic Terminology

The characteristics iisted are those which are commonly considered when, say, a designer must choose a bearing to be used in a new spindle or when a potential user must evaluate a given design in a purchase decision. Again, certain points are worth noting.

"First Cost" refers to the purchase and installation price in dollars, as opposed to another cost mentioned later.

"Life" expectancy assumes intermittent operation and normal maintenance. 
"Space" required is simply the amount of physical room the bearing requires and, in the case of the hydrostatic, the pump, piping, etc.

"Adjustability" is the degree to which operating characteristics of a bearing can be varied at will.

"Overload Capacity" refers to the amount of extra load a bearing can handle over its design load before a significant reduction in life expectancy, increase in friction, etc., are noticed.

"Ambient Effects" is included to indicate the sensitivity of a bearing to its environment, such as external temperature, vibration, etc.

Finally, "Pickup" refers to the distance the journal centerline will move as the bearing is brought to operating speed from rest.

\section{Characteristic Ratings}

In general, a given characterist1c of a beariing (such as "Life") has been classed according to good, No. 1 (shortest); better, No. 2 (medium); and best, No. 3 (longest expectancy); etc. The good, better, and best codifications are true for all but the "Radial Accuracy" characteristics for which the inverse is true. Based on classic Total Indicated Runout measurements, No. 3 represents the best accuracy ( 0 to 0.00005 inches Total Indicated Runout); No. 2, medium accuracy (0.00005 to 0.0002 inches); and No. 1, low accuracy (0.0002 inches and up).

Overall Bearing Ratings

In the "Rating" column, two rating numbers have been assigned each bearing.

The one at the left-hand top is simply the sum of all the numbers to its left, excluding that in the "Radial Accuracy" column. The larger the number, the less desirable is the bearing from all aspects considered in Figure 5. Note, however, this assumes each aspect carries the same weight, which will probably not be the case in all situations. The number at the bottomright is a sum divided by the "Radial Accuracy" column number. This can be interpreted loosely as a "cost-per-unit-accuracy" 
figure (or "headache ratio," if you prefer), where the cost is not necessarily in dollars alone. The smaller the number, the more desirable is the bearing from an accuracy standpoint.

Conclusions

A chart such as Figure 5 serves several useful purposes, the most obvious of which is to provide a quick comparison among bearings.

For example, using figures from the Rating Column, bearing classes may be arranged in order of descending preference as Ball, Hydrostatic, Roller, and Hydrodynamic bearings. Further, Axial-Contact type, or Needle-Roller bearings are preferred over Three-piece Solid Roller type; etc. Note also that the least preferable of all is the kingsbury bearing as evidenced by the continuing reduction in its use.

Because of the many generalizations necessary to construct a chart such as Figure 5, conclusions drawn from it may have to be modified in light of specific data at hand. For example, although the chart indicates Axial-Contact ball bearings are preferred, the fact that separate trust bearings must be in cluded may bring up further complications in terms of cost, space required, etc.

Distributed as a useful source to accompany the material presented herein is Attachment A (12 pages) which contains considerable technical data taken from the book, "Anti-Friction, Bearings." The original pages are numbered from 151 through 161 , and page 211. The data include (1) contemporary measurement definitions and bearing nomenclature; (2) gaging, practices associated with bearings; and (3) typical high-accuracy bearing specifications. Permission for use is gratefully acknowledged to the author, Hudson T. Morton. 


\section{ABSTRACT OF BEARING DEVELOPMENTS AND DATA ON SPINDLES}

H. S. Green and A. E. Rains

Mechanical Research and Development

The Dow Chemical. Company

Rocky Flats Division

Golden, Colorado

(RFP-734).

\section{Address delivered at the Seventh International Machine Tool Design and Research Conference University of Birmingham \\ Birmingham, England}

September $12-16,1966$

Permission for use of the materials in Attachment $A$ has been granted by the author and publisher, Hudson T. Morton. Taken from Second Edition of "Anti-Friction Bearings," 1606 Morton Avenue, Ann Arbor, Michigan, 1965. 


\section{THIS PAGE}

\section{WAS INTENTIONALLY \\ LEFT BLANK}

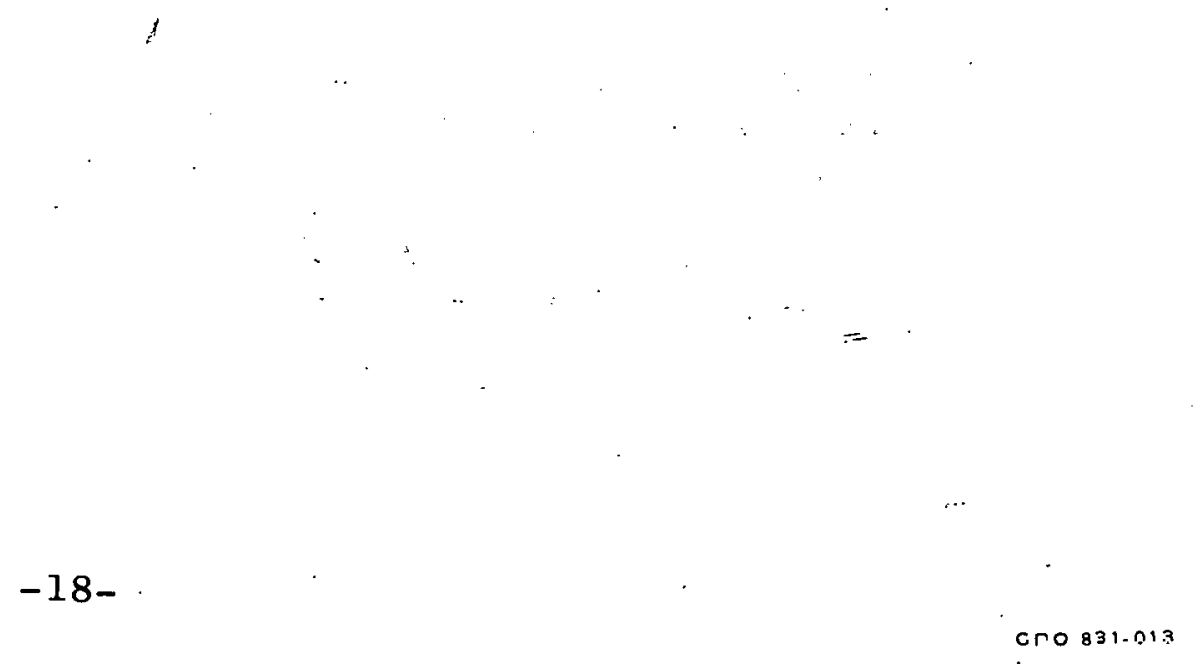




\section{ABSTRACT OF BEARING DEVELOPMENTS AND DATA ON SPINDLES}

\section{MEASUREMENT DEFINITIONS}

Before measurements can be made or tolerances established, certain definitions are necessary as outlined below:

Radial Ball Bearing: An anti-friction bearing primarily designed to support load perpendicular to shaft axis.

Cylindrical Roller Bearing: An anti-friction bearing with rolling surface parallel to bearing axis.

Magneto Ball Bearing: A separable single row ball bearing of radial or low contact angle type.

Airframe Bearing: An anti-friction bearing especially designed for use in the control systems and surfaces of aircraft.

Thrust Ball Bearing: An anti-friction bearing primarily designed to support load parallel to shaft axis.

Tapered Roller Bearing: An anti-friction bearing having one or two rows of tapered rollers.

Bore and Outside Diameters: Defined by the symbol explanation.

Bearing Ring Width: A bearing ring width is the distance between the points of intersection between the two sides of the ring and a straight line perpendicular to the plane, tangent to the reference side of the ring.

Radial Runout:

Inner Ring Raceway: The radial runout of an inner ring raceway is the difference between the greatest and the smallest radial distance between the bore surface and the middle of a raceway on the outside of the ring.

Outer Ring Raceway: The radial runout of an outer ring raceway is the difference between the greatest and the smallest radial distance between the outside surface and the middle of. a raceway on the inside of the ring.

Side Runout With Bore: The reference side runout-with bore is the difference between the greatest and the smallest axial distance between a plane perpendicular to the ring axis' and the reference side of the ring at a radial distance from the axis equal to half the mean inner ring raceway diameter.

Outside Cylindrical Surface Runout With Side: The outside cylindrical surface runout with reference side is the greatest total variation of the relative position, in radial direction, of points on the same generairix of the outside surface at a distance of 3.5 times the minimum ring chamfer dimensions from the sides of the ring.

Groove Runout With Side:

Raceway Groove; The raceway groove runout with reference side of a groove type radial ball bearing ring is the difference between the greatest and the smailest axial distance between the plane tangent to the reference side of the ring and the middle of a raceway groove.

Radial Internal Clearance of Master Bearing: The internal radial clearance" of a radial contact master bearing, the form errors of which are negligible, is the outer ring raceway diameter minus the inner ring raceway diameter minus twice the rolling body diameter. 


\section{ANTI- FRICTION BEARINGS}

Symbols :

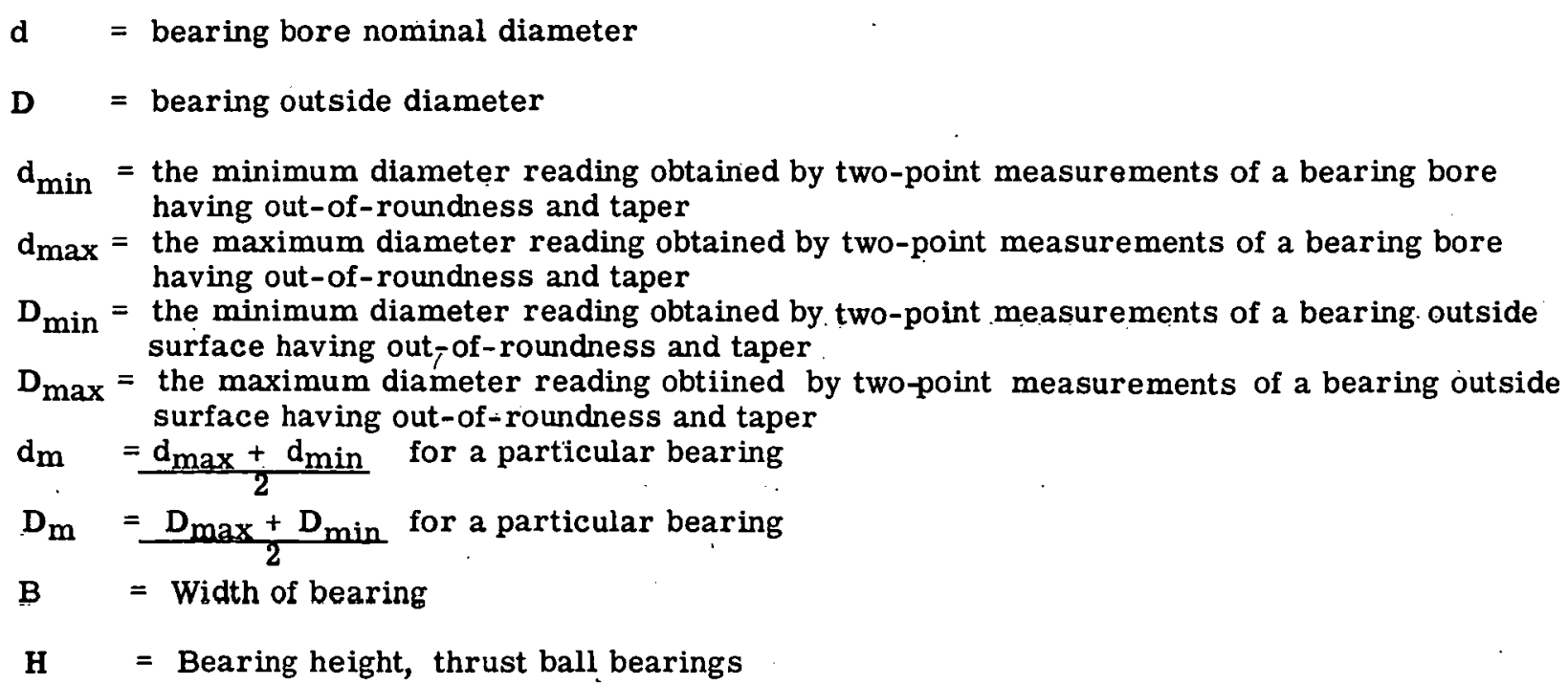

In this Standard the headings: "Bore Tolerance Limits" and "Outside Diameter Tolerance Limits" are used in preference to the headings: "Tolerance for Bore" and "Tolerance for Outside Diameter", respectively. These new headings are based on terminology shown in American Standard Preferred Limits and Fits for Cylindrical Parts, B4.1-1955. The following sketch will serve to clarify the significance of this nomenclature:

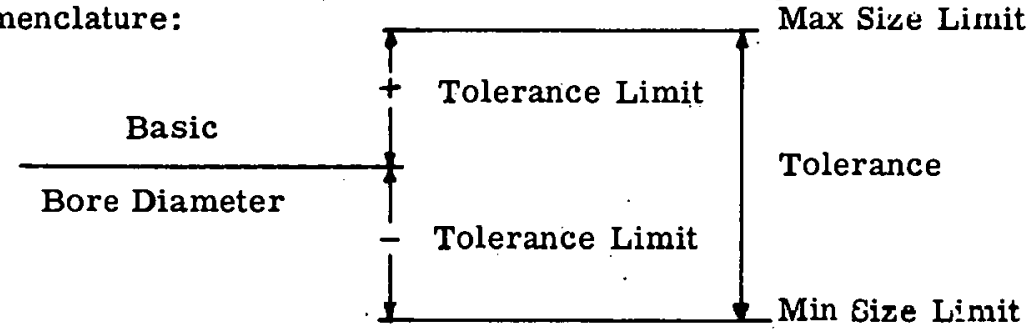

Inch-Millimeter Conversion Factor

Because the majority of bearings are made to metric dimensions and the tolerances are in inches, it is necessary to use a common conversion. The following factor (American Standard Practice for InchMillimeter Conversion for Industrial Use, B48. 1-1933 (R1947) is used: 1 inch $=25.4$ mm. Therefore the conversion tables given in the American Standard B48. 1-1933 (R1947) should be used in the manner indicated by this standard, or if no conversion tables are availapie, equivalents should be calculated by use of the factor $25.4 \mathrm{~mm}$. To convert inches to millimeters, multiply the inches by 25.4. To convert millimeters to inches, divide the millimeters by 25. 4 .

When a decimal value is to be rounded off to a lesser number of places than the total number available, the procedure shoula be as follows:

When the figure next beyond the last figure to be retained is less than 5 , the last figure retained should not be changed.

When the figure next beyond the last figure to be retained is more than 5 , the last figure retained should be increased by 1 .

When the figure next beyond the last place to be retained is exactly 5 with zeros beyond, the last figure retained, if even, should be unchanged; if odd, it should be increased by 1. 


\section{STANDARD BEARING IDENTIFICATION CODE, DIMENSIONS AND TOLERANCES}

\section{GAGING PRACTICE}

AFBMA ${ }^{10}$ and ASA $^{11}$ established standards for methods of measuring while ISO has similar standards under consideration. These statements are shown herewith subject to change by the standardizing organizations.

\section{Methods of Measuring}

\subsection{General}

2.1.1 Measurements of the various dimensions and runouts can be performed in different manners using different kinds of gauging equipment and with different degrees of accuracy. In this section, methods are described which are commonly used by bearing users and which, as a rule, give an accuracy sufficient for practical purposes. Bearing manufacturers frequently use specially designed gauging equipment to increase the speed and accuracy of gauging.

2.1.2 Measurements of dimensions are performed by comparing the actual part with appropriate gauge blocks or masters which must conform with those used by the National Bureau of Standards at 68 degrees F.

\subsubsection{For such comparison an indicator, calibrated and of appropriate sensitivity, is used.}

2.1.4 Before measurement is made, the part to be measured, the indicator and the gauge block or master must be brought to the temperature of the room in which the measurements are to be made.

2.1.5 To avoid undue deflection of thin rings, indicator pressures should be minimized and if significant distortion is present, a load deflection factor should be introduced to correct the measurement to the free unloaded value.

2.1.6 In all cases when arbor methods of measuring runout are used, the rotational accuracy of the arbor must be determined so that subsequent bearing measurements may be suitably corrected if appreclable arbor inaccuracy is involved.

2.1.7 In measuring ring widths and width variation of the smalier sizes of bearings, serrated anvils may be used for ring support if no significant $r$ ing warpage is present.

\subsection{Methods of Measuring Inner Ring}

2.2.1 Bore: Method applicable to all types of rolling bearings, not only that illustrated.

2.2.1.1 For determining "single diameters" of a bore, use apparatus arranged for two point measuring. Measure single diameters in many angular directions and also in many radial planes. In this manner $d_{m i n}$ and $d_{\max }$ are established from which the mean diameter $d_{m n}=\frac{a_{m i n}+a_{m a x}}{2} i s$ obtained.

If the size or section of the bearing inner ring is such that, with the bearing axis in a horizontal position, the bore measurement is influenced by gravity, the bearing should be placed with the axis in a vertical position and, if necessary, a lower gauge load be used.

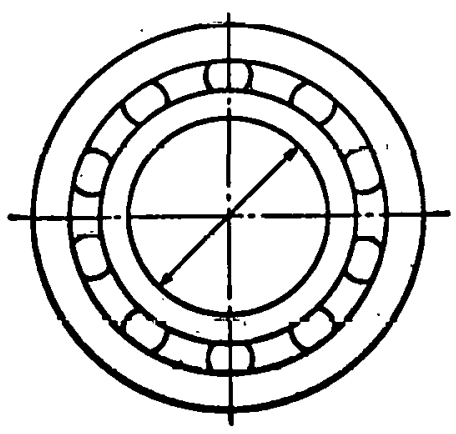




\section{ANTI-FRICTION BEARINGS}

that illustrated.

2.2.2 Width of Individual Ring: Method applicable to all types of rolling bearings, not only

2.2.2.1 Support one side of the inner ring on three buttons, leaving the outer ring free. App an indicator against the other side of the inner ring directly opposite one button. Take indicator readIngs while rotating the inner ring one revolution.

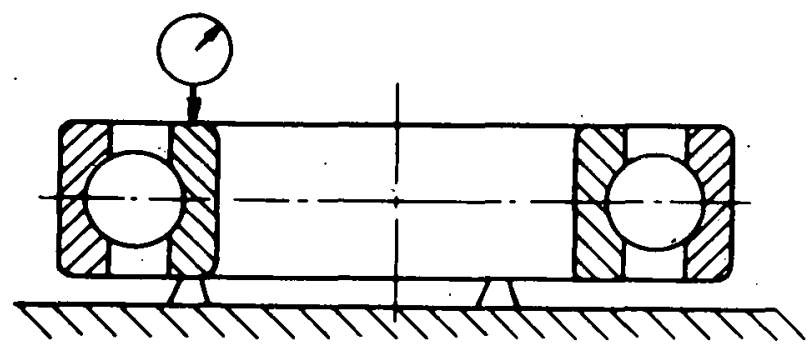

\subsubsection{Width Variation of Individual Ring}

2.2.3.1 Use the same method as applied to measuring of the width.

\subsubsection{Radio.l Funout}

2.2.4.1 Method applicable to groove type bali bearings (except single row angular contact) and cylindrical roller bearings.

2.2.4.1.I Mount the bearing on an arbor having a taper of .0001 to .0002 inch on diameter per inch of length and apply the arbor between two accurate centers or other sultable supports so that it can be rotated. Apply an indicator as close to the center line of the outer ring as possible. Hold the outer ring stationary, resting on the balls or rollers, and take indicator readings while. rotating the inner ring one revolution.
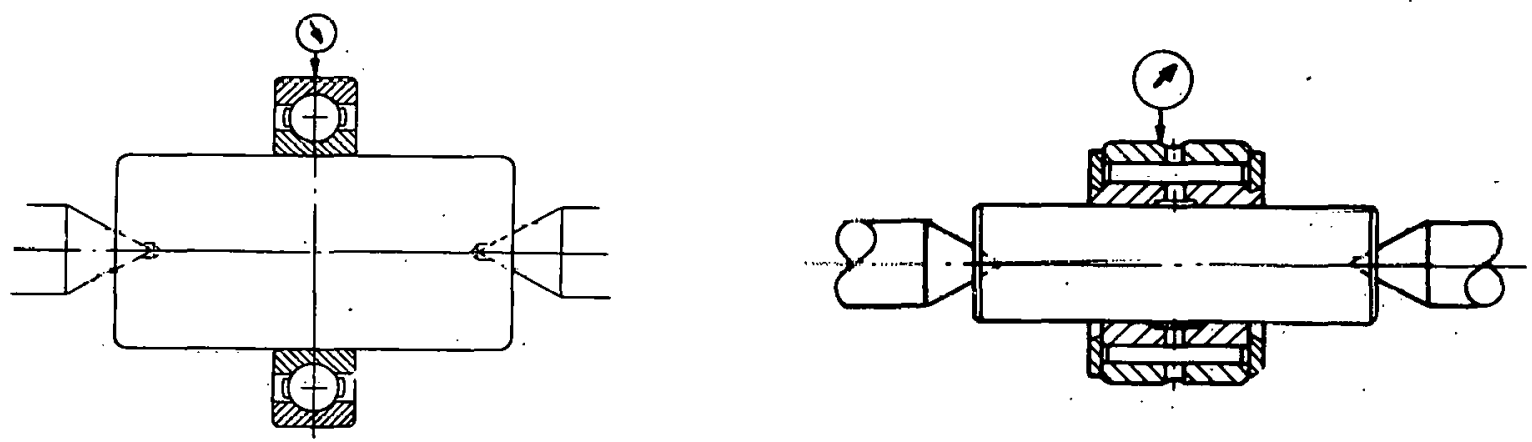

2.2.4.2 Method applicable to groove type ball bearings (including single row angular contact) and tapered roller bearings.

2.2.4.2.1 Support the outer ring and apply a dynamically stable co-axial light load to the reference or thrust side of the inner ring to ensure contact between balls or roliers and raceways. Apply an indicator to the center line of the inner ring bore and take indicator readings while rotating the inner ring one revolution.

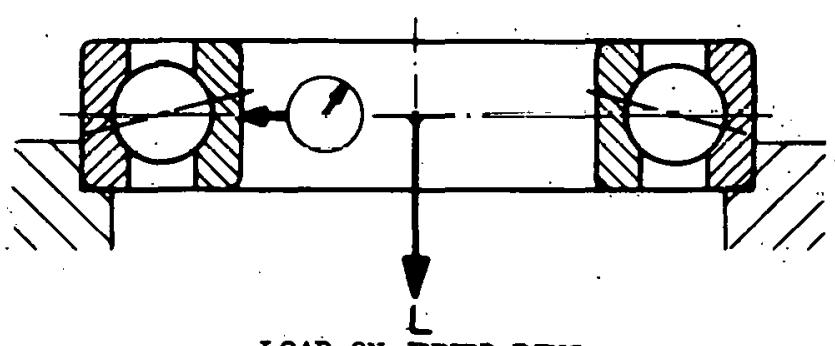

A-Page 4 of 12

LOAD. ON INNER RING

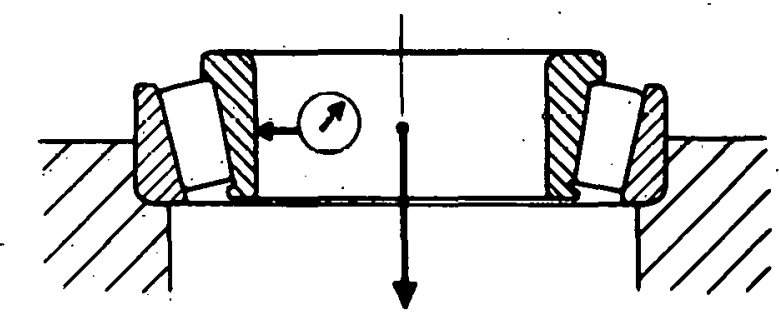

LOAD ON CONE 


\section{STANDARD BBARI HG IDEMTIFICARION DODE, DI MGMSIONS AND TOL HRAYCES}

\subsubsection{Reference Side Runout with Bore}

\subsubsection{Method applicable to all types of rolling bearings, not only that illustrated.}

2.2.5.1.1 Mount the bearing on an arbor having a taper of .0001 to .0002 inch on diameter per inch of length and apply the arbor between two accurate centers so that it can be rotated. Apply an indicator against the reference side of the inner ring on a diameter as equal to the mean raceway diameter as possible. Take indicator readings whlle rotating the inner ring one revolution. Correction must be made for inaccuracy of the arbor.

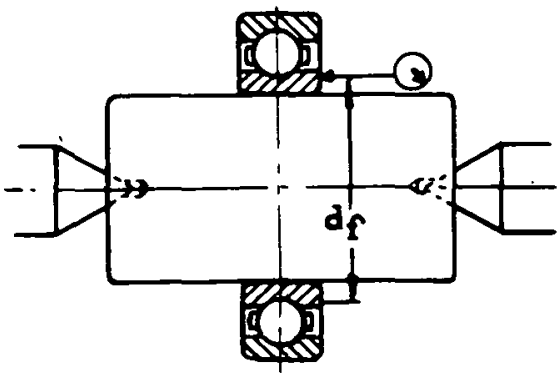

2.2.5.2 Alternate method applicable to all types of rolling bearings with dimensions conforming to the basic plan for boundary dimensions, AFBMA Standard Section No. 2, Table 1 , and chamfer according to AFBMA Standard Section No. 3.

2.2.5.2.1 Support the reference side of the inner ring on a flat plate, leaving the outer ring free, and locate the inner ring against, a stop at a distance of $3.5 \mathrm{r}$ from the lower side surface. Apply an indicator directly above the stop at a distance of $3.5 \mathrm{r}$ from the upper side surface as illustrated. Take indicator readings while rotating the inner ring one revolution and multiply the difference between the greatest and the smallest reading by the ratio $\mathrm{d}_{\mathrm{f}} / 2 \mathrm{~B}_{\mathrm{e}}$. This product is the "Reference Side Runout with the Bore".

$d_{f}=a$ diameter as equal to the mean raceway diameter as possible.

$\mathrm{B}_{\mathrm{e}}=$ the distance between the locating stop and the indicator contact.

$r$ = the maximum shaft fillet radius which the bearing chamfer must clear (see AFBMA Standard Section No. 2, Table 1).

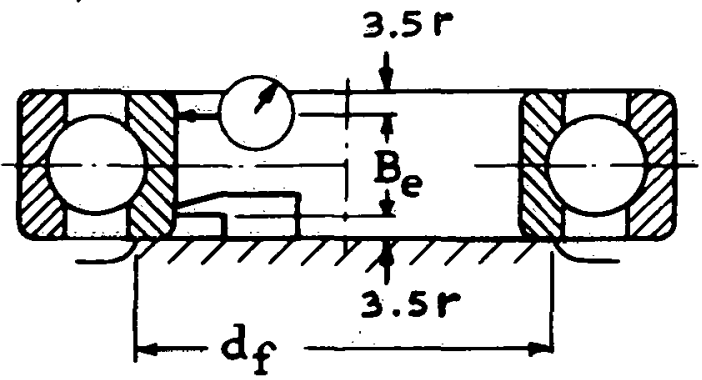

2.2.6 Groove Runout with Reference Side: Method applicable to groove type ball bearings (including single row angular contact).

2.2.6.I Support the outer $\mathrm{ring}$ and apply a dynamically stable co-axial light load to the inner ring to assure contact between the balls and the raceways. Apply an indicator on the reference side of the inner ring and take indicator readings while rotating the inner ring one revolution.

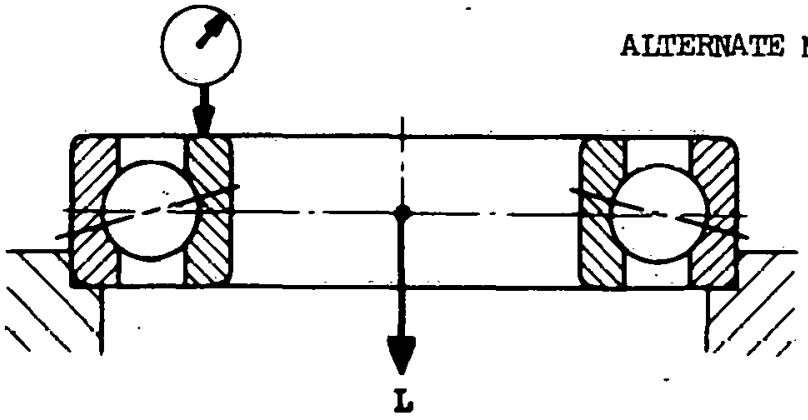

IOAD ON IINER RING

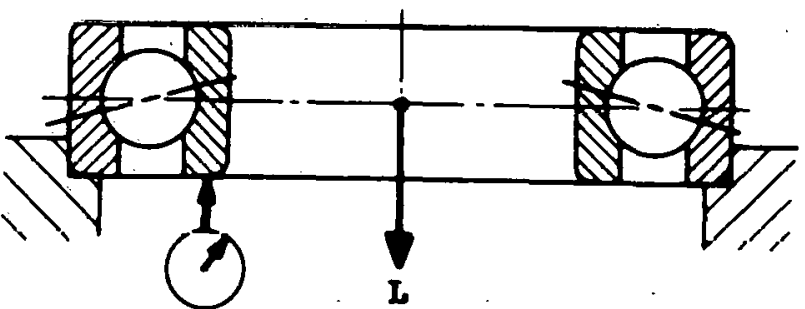

TOAD ON INNER RTIG
A-Page 5 of 12 


\section{ANTI-FRI CTION BEARINGS}

\subsection{Methods of Messuring Outer Ring}

trated.

2.3.1 Outslde Diameter: Method applicable to all types of roliling bearings, not only those 111

2.3.1.1 For determing "single diameters" of an outside cylindrical surface use apparatus arranged for two point measuring. Measure single diameters in many angular directions and also in many radial planes. In this manner $D_{m i n}$ and $D_{\max }$ are established from which the mean diameter $D_{m}=\frac{D_{\min }+D_{\max }}{2}$ is obtained. If the size or section of the bearing outer ring is such that, with the bearing axis in a horizontal position, the outside diameter messure is influenced by gravity, the bearing should be placed with the axis in a vertical position.
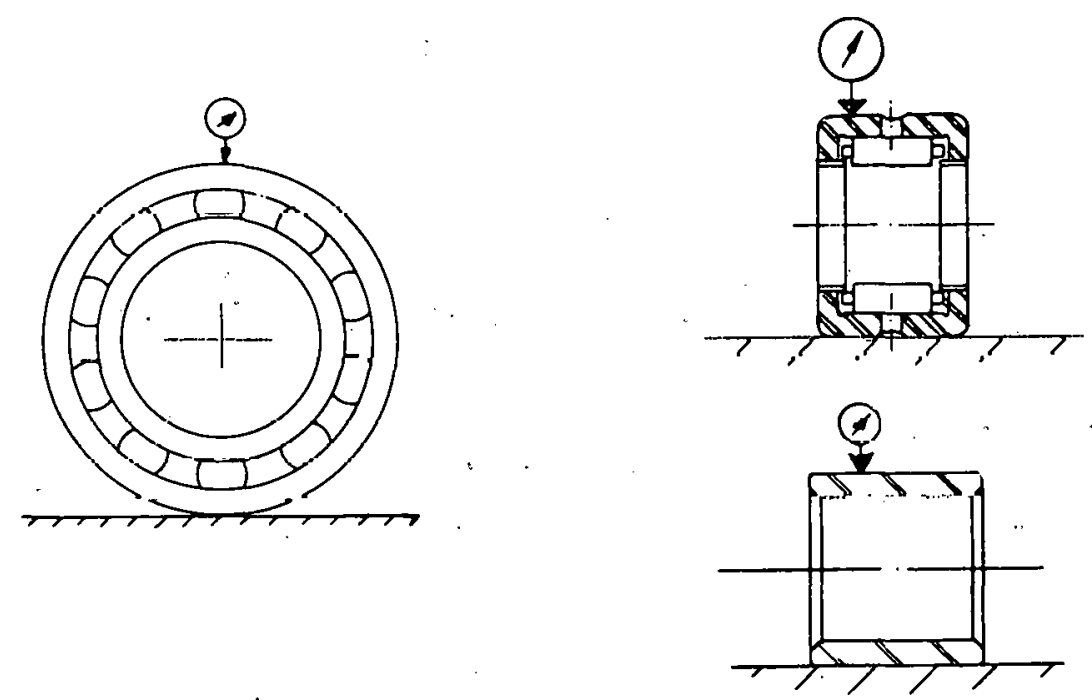

2.3.2 Width of Individual Ring: Method applicable to all types of rolling bearings, not only to those illustrated.

2.3.2.I Support one side of the outer ring on three. buttons, leaving the inner ring free, Apply an Indicator against the other side of the ring directly opposite one button. Take indicator readings while rotating the outer ring one revolution.
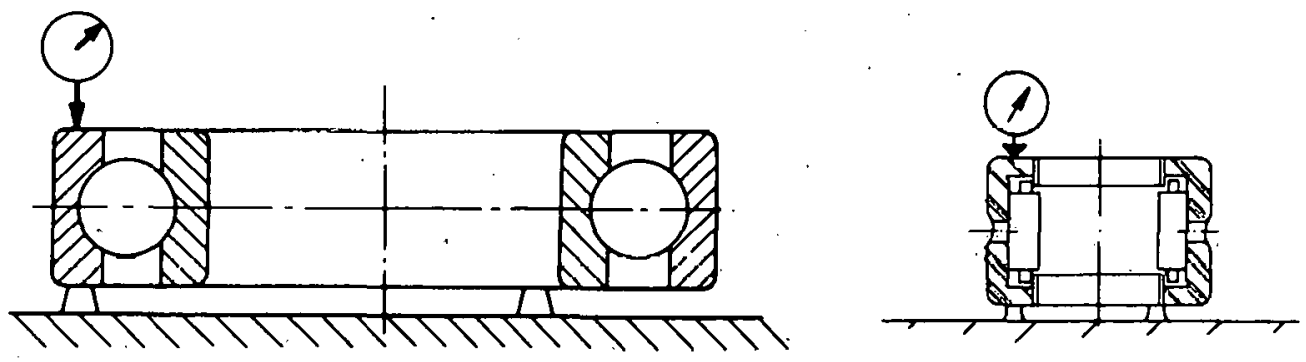

\subsubsection{Width Variation of Individual Ring}

2.3.3.1 Use the same method of measuring as applied to measuring of the width.

\section{3 .4 Radial Ruriout}

2.3.4.1 Method applicable to groove type ball bearings (except single row angular contact) and cylindrical roller bearings.

A-Page 6 of 12 


\section{STANDARD BEARING IDENTIFICATION CODE, DIMHHSIONS AND TOL WRANCES}

2.3.4.1.1 Mount the bearing on an arbor having a taper of .0001 to .0002. Inch on diameter per inch of length and apply the arbor between two centers or other suitable support so that it is firmly sated. Apply an indicator as close to the center of the outer ring as possible. Take indicator sadings while rotating the outer ring one revolution.
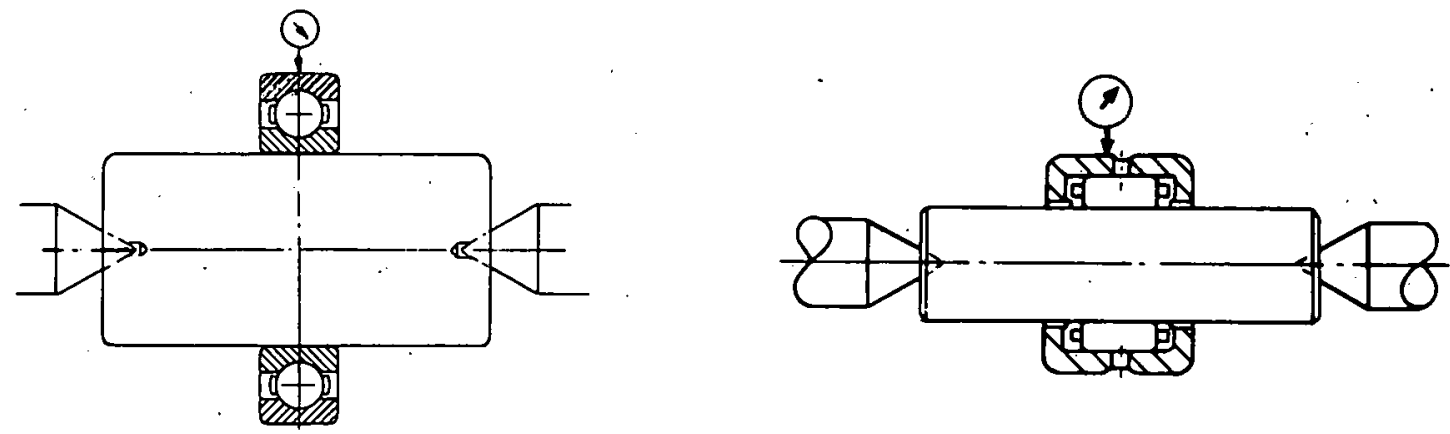

2.3.4.2 Method applicable to groove type ball bearings (Including single row angular contact) and tapered roller bearings.

2.3.4.2.1 Support the Inner ring and apply a dymamically stable co-axial light load to the reference side or thrust side of the outer ring to ensure contact between balls or rollers and raceways. Apply an indicator to the middle of the outer cylindrical surface and take indicator readings while rotating the outer ring one revclution.
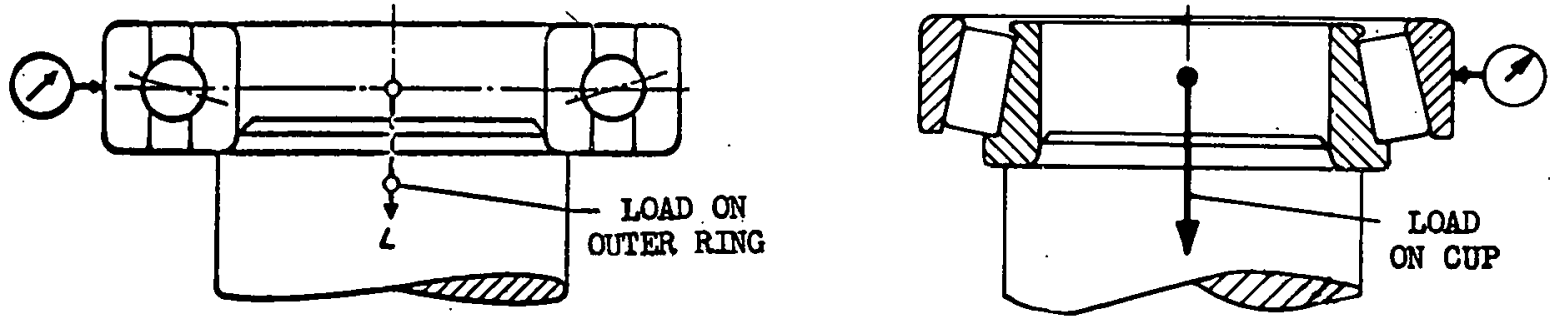

2.3.5 Outside Cylindrical Surface Runout with Reference Side: Method applicable to all types of rolling bearings of dimensions conforming to the basic plan for boundary dimensions in AFBMA Standard Section No. 2, Table 1, width series 1 or narrower and chamfers according to AFBMA Standard Section No. 3.

2.3.5.1 Support the reference side of the outer ring, leaving the inner ring free, and locate the outside cylindrical surface against a stop a distance of $3.5 \mathrm{r}$ from the lower side surface. Apply an ind1cator directly above the stop at a distance of $3.5 x$ from the upper side surface as 111 ustrated. Take indicator readings while rotating the inner ring one revolution.

$r=$ maximum housing fillet radius which the bearing chamfer must clear (see AFBMA Standard Section No. 2, Table 1).

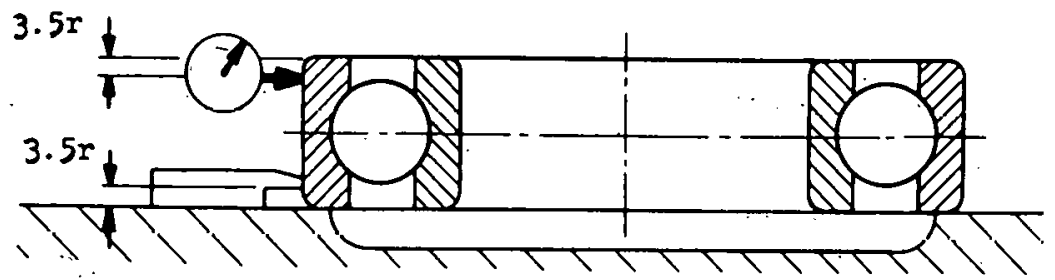

2.3.6 Groove Runout with Reference Side: Method applicable to groove type ball bearings including single row angular contact ball bearings.

2.3.6.I Support the inner ring and apply a dynamically stable co-axial light load to the outer ring to ensure contact between the balls and the raceways. Apply an indicator on the reference or thrust 


\section{ANTI-ERI CTION BEARINGS}

side of the outer ring and take indicator readings while rotating the outer ring one revolution.

\section{AITERNATE METHODS}
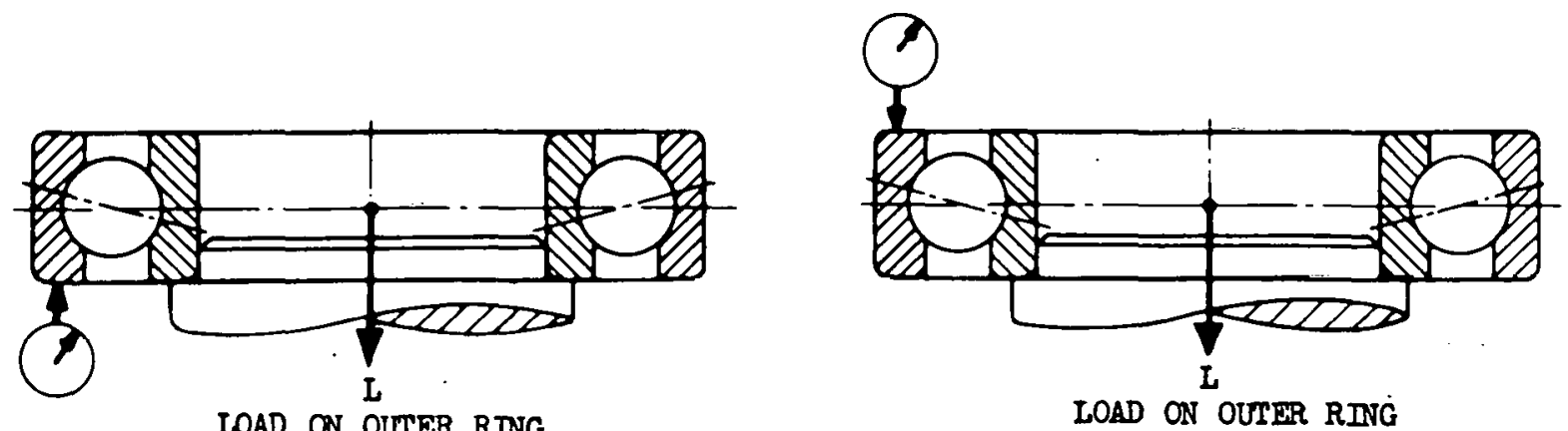

2.3.7 Diameter Under the Rollers: Method applicable to cylindrical roller bearings and needle vearlints.

2.3.7.1 For bearings with normal outer ring use appropriate "Go" and "No Go" plug gauges.

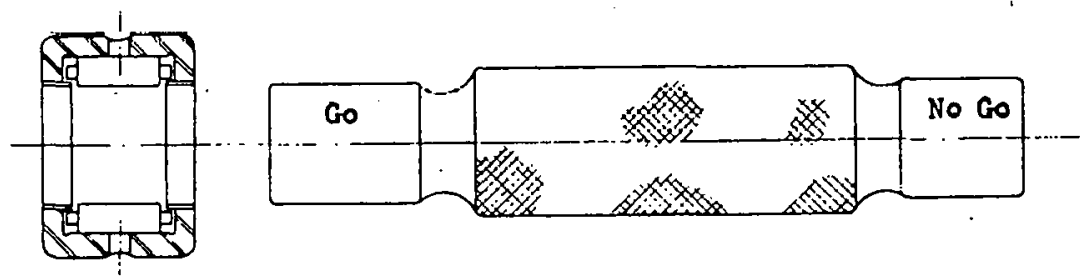

2.3.7.2 For determining the diameter under the rollers in needle bearings having an outer ring of the draw shell type, the bearing is first pressed into a steel ring of sufficient thickness to make the bearing ring round. Appropriate "Go" and "No Go" gauges are then used.

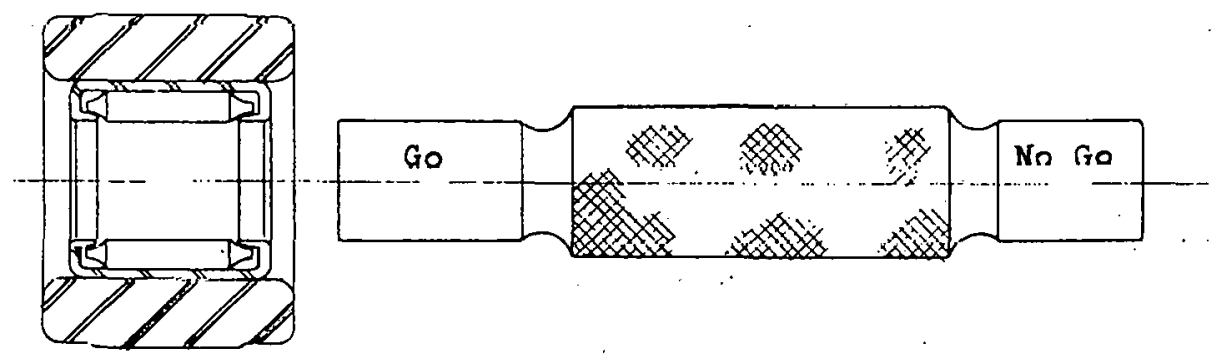

\subsection{Radial Runout of Needle Cam Foliowers}

2.4.1 Mount the bearing in a clamp as indicated below and apply an indicator on the center of the outer ring. Take indicator readings while rotating the outer ring one revolution.

A-Page 8 of 12

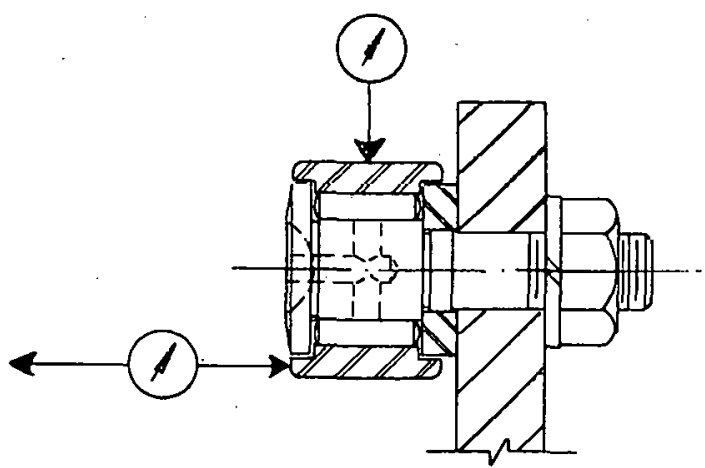




\section{STANDARD BEARING IDENTIFI CATION CODR, DIMENSIONS AND TOL RRANUES}

\subsection{Method of Measuring Side Runout of Lock Nuts}

2.5.1 Mount the lock nut on a tight fitting threaded arbor and locate tric arbor between two snters so that it can be rotated (a tapered arbor is not acceptable for this purpose). Apply an ind1cator to the contact or chamfer side of the lock nut and take. indicator readings while rotating the arbor one revolution.

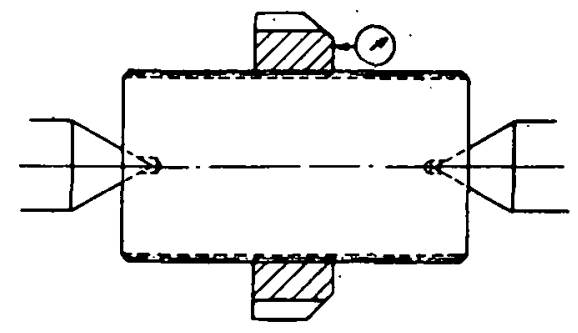

2.6 Method of Measuring Radial Internal Clearance in Single Row Radial Contact Ball Bearings

2.6.1. In the past most companies have measured bearing looseness by determining the amount of end play. On the other hand, some companies have always measured looseness radially. It has become recognized that the latter method is more correct because it is not disturbed by unavoidable variation in the groove radii of both rings. Furthermore, radial play, as a rule, is of greater significance to the bearing user than is axial play.

2.6.1.1 It is not an easy matter to precisely measure the internal looseness in a single row ball bearing; also, different types of gauges may give different results. In order to overcome these difficulties and make it possible for a bearing consumer to determine if bearings which he has received are within standard tolerances, Without resorting to special expensive gauges, it was felt that the method used for this purpose should be simple and possible to perform with equipment which is normally available in any well equipped shop.

2.6.1.2 It was realized by The Anti-Friction Bearing Manufacturers Association that such a simplified method would not be practical when checking large numbers of bearings. On the other hand, 1t gives sufficiently accurate values so that in case of disagreement it would be possible for both parties to determine and agree upon the magnitude of looseness existing in a particular bearing. Those who prefer to use some particular type of gauge for the sake of saving time may do so by calibrating this faster gauge with master bearings as defined in AFBMA Standard Section No. 3. The Standard Method should constitute the reference base in any case where a difference of opinion or dispute exists.

\subsubsection{Method of Measuring}

2.6.2.1 Fasten the inner ring of the assembled bearing on a horizontal flat plate with a shim (a plece of ordinary writing paper.002 inch to .003 inch thick when handling small bearings, and two or, if necessary, three such picces when handling large bearings) between the ring and the plate.

2.6.2.2 Apply a sensitive indicator against the center of the outer ring $0 . D$. on the center-line of the ball groove. Hold the outer ring in contact with the rest of the bearing in Direction A with care not to lift the opposite side, and move repeatedly at this point up and down and oscillate circumferentially (for the purpose of moving the ball to the bottom of the ball groove) unt1l the indicator can be seen to give a generally maximum reading.

2.6.2.3 While continuing to hola the outer ring gent.ly in contact with the rest of the bearing in Direction A, move the outer ring at this point first up and then down without circumferential motion. When the halls pass through the bottom of the grooves, the indicator will show a maximum reading, which is recorded.

2.6.2.4 Without changing the general location of the outer ring, hold it in contact with the rest of the bearing in Direction $B$, with care not to lift the opposite side, and move repeatedly at this point up and down and osclilate circumferentially a small amount (for the purpose of moving the balls of the opposite side to the bottom of the bail grooves) until the indicator can be seen to give a generally inimum reading. 


\section{ANTI-FRICTION BEARINGS:}

2.6.2.5 Then, while continuing to hold the outer ring gently in contact with the rest of the bearing in Direction.B, move the outer ring at this point first up and then down without circumferential motion. When the balls pass through the bottom of the grooves, the indicator will show a minil reading, which is recorded. The difference between the two recorded readings is the radial loosene

2.6.2.6 To compensate for possible out-of-roundness of the outer ring, repeat the. saine procedure several times at different anguiar positions of the outer ring in relation to the indicator. To compensate for possible out-of-ruundness of the inner ring, repeat the same procedure with this ring at different angular positions in relation to the indicator. Take the average of the several readings as the looseness of the bearing.

NOTE: If the indicator needle does not pass through a clear maximum or minimum reading, respectively, the shim is probably too thin.

2.6.2.7 When handling large and heavy bearings, it is helpful to insert three pieces of flat stock, each about $1 / 2$ inch thick, between the flat plate and both bearing rings. These pleces should be located radially with two of them relatively close together, one at.each side of the indicator point, and the third directiy opposite the indicator. The paper shims in this case are placed between the inner ring and these pleces. outer ring.

2.0.2.8 When handling small bearings, it is helpful to use a rubber tipped stick for moving the

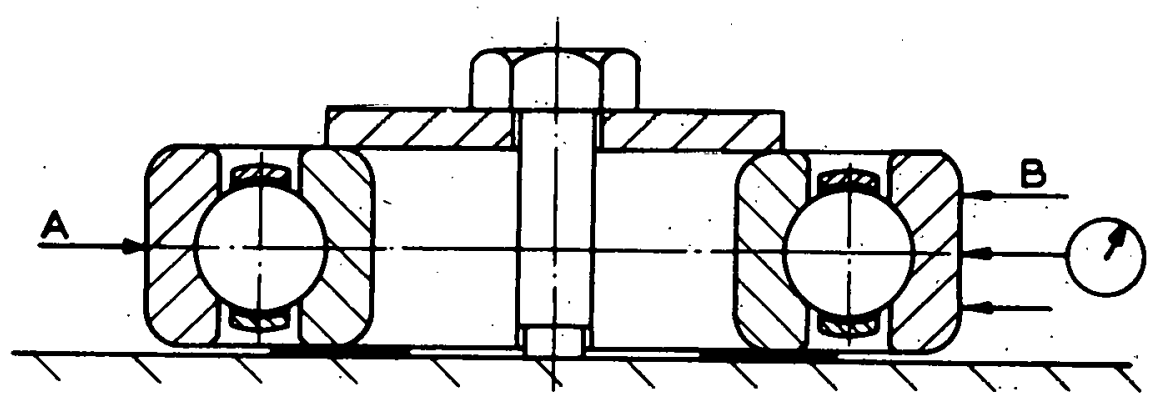




\section{GAGING LOADS}

The new standards for measurement are based upon equipment capable of recording dimensions with gaging loads converted to zero. Where such equipment is not available, former gaging loads are printed herewith but are not included in bearing standards:

Former Gaging Loads

\begin{tabular}{|c|c|c|c|c|c|}
\hline \multirow[b]{3}{*}{$\begin{array}{c}\text { Inner Ring } \\
\text { Bore }\end{array}$} & \multicolumn{2}{|c|}{$\begin{array}{l}\text { Nominal Diameter } \\
\text { Millimeters }\end{array}$} & G age Load & \multicolumn{2}{|c|}{ Gage Point Radius } \\
\hline & over & Incl. & \multirow[b]{2}{*}{$\begin{array}{l}\text { Not exceeding } 7 \text { ozs. (198 grams) } \\
\text { Not exceeding } 7 \text { ozs. (198 grams) } \\
12 \text { ozs. }\end{array}$} & \multirow[b]{2}{*}{$\begin{array}{l}.8 \mathrm{~mm} \text {. } \\
\text { 2. } 5 \mathrm{~mm} \text {. } \\
\text { 2. } 5 \mathrm{~mm} \text {. }\end{array}$} & \multirow[b]{2}{*}{$\begin{array}{l}=.032 \text { inch } \\
=.098 \text { inch } \\
=.098 \text { inch }\end{array}$} \\
\hline & $\begin{array}{rr}0 & \\
9 & \\
30 & \text { and }\end{array}$ & $\begin{array}{r}9 \\
30 \\
\text { up }\end{array}$ & & & \\
\hline $\begin{array}{l}\text { Outside } \\
\text { Diameter }\end{array}$ & 0 and & up & Not exceeding 7 ozs. (198 grams) & 2. $5 \mathrm{~mm}$ & $=.098 \mathrm{inch}$ \\
\hline
\end{tabular}

Former Radial Internal Clearance Measuring Loads

\begin{tabular}{|c|c|}
\hline Loads & For Bearlngs with Bore \\
\hline $\begin{array}{lllll}2-1 / 2 & \mathrm{~kg} . & \text { or } & 5-1 / 2 & \mathrm{lbs} . \\
5 & \mathrm{~kg} . & \text { or } & 11 & \mathrm{lbd} . \\
15 & \mathrm{~kg} . & \text { or } 33 & \text { lbs. }\end{array}$ & $\begin{array}{l}\text { over } 0 \mathrm{~mm} \text {. to and including } 18 \mathrm{~mm} \text {. } \\
\text { over } 18 \mathrm{~mm} \text {. to and including } 50 \mathrm{~mm} \text {. } \\
\text { over } 50 \mathrm{~mm} \text {. to and including } 140 \mathrm{~mm} \text {. }\end{array}$ \\
\hline
\end{tabular}

\section{SUMMARY}

By following the information given in this chapter, numbers, dimensions, tolerances and methods of gaging; an engineer can select a standardized bearing for his application knowing its dimensional characteristics which should be capable of use in nearly every normal application.

\section{BIBL IOG RAPHY}

1. Handbook, Society of Automotive Engineers, 1911.

2. American Standard B3.6-1962, "Boundary Dimensions for Ball and Roller Bearings," Amërican Standards Association, New York.

3. AFBMA Standards, Section 2, "Boundary Dimensions for Ball and Roller Bearings," May, 1960. Anti-Friction Bearing Manufacturers Association; New York.

4. International Standards Association was active until 1940.

5. International Organization for Standards was formed after World War II with Technical Committee 4 in charge of bearing standardization.

6. Bearing Manual No. 59 , published by Bearing Manual, Inc., Broadview, III.

7. AFBiNA Standards Section 5, "Bearing Identification Core for Anti-Friction Ball and Roller Bearings," Anti-Friction Bearing Manufacturers Association, New York.

8. ASA Standard B54.1-1960, "Identification Code for Ball and Roller Bearings."

9. ISO Recomméndation R300, "Identification Code for Rolling Bearings."

10. AFBMA standards, Section 4, "Ball and Roller Bearing Standard Gaging Practices," December 1964, AFBMA, New York.

11. American Śtandard B3.4-1965, "Gaging Practices.for Ball and Roller Bearings," American Standards Association. New York.

12. I30 Recomnendation R15-1955, "Ball and Roller. Bearings;" International Organization for Standards, Stockholm, Sweden.

13. Anerican Standard B3.5-1960, "Tolerances for Ball and Roller Bearings, Anierican Standards Assoclat lon, New York.

1.4. AFBMA Standards, Section 3, "Tolerances. for Ball and Roller Bearings," Anti-Friction Bearing Manufacturers Association, New York.

15. ISO Recommendation R-199 - 1961, "Tolerances for Ball and Roller. Bearings." 


\section{STANDARD BEARING IDENTIFICATION CODE, DIMENSIONS AND TOLERANCES Table 9-XIVII}

ABEC 9

TOLERANCE LIMITS FOR METRIC AND. INCH DIMENSION RADIAL BALL BEARINGS

Tolerance Limits in 0.0001 Inch

INNER RING

\begin{tabular}{|c|c|c|c|c|c|c|c|c|c|}
\hline \multicolumn{4}{|c|}{ Basic Bore Diameter } & \multicolumn{2}{|c|}{$\begin{array}{c}\text { Bore Tolerance } \\
\text { Limits }\end{array}$} & \multirow{2}{*}{$\begin{array}{l}\text { Radial } \\
\text { Runout } \\
\text { Max. }\end{array}$} & \multirow{2}{*}{$\begin{array}{l}\text { Width } \\
\text { Varlation } \\
\text { Max. }\end{array}$} & \multirow{2}{*}{$\begin{array}{l}\text { Reference Side } \\
\text { Runout w:th } \\
\text { Bore } \\
\text { Max. } \\
\end{array}$} & \multirow{2}{*}{$\begin{array}{l}\text { Groove Runout } \\
\text { with Reference } \\
\text { Side II } \\
\text { Max. }\end{array}$} \\
\hline Over & Incl. & Over & Incl. & $\mathrm{d}_{\mathrm{min}}$ & $d_{\max }$ & & & & \\
\hline
\end{tabular}

OUTER RING

\begin{tabular}{|c|c|c|c|c|c|c|c|c|c|}
\hline \multicolumn{4}{|c|}{ Basic Outside Diameter. } & \multicolumn{2}{|c|}{$\begin{array}{l}\text { Outside Diameter } \\
\text { Tolerance Limits }\end{array}$} & \multirow{2}{*}{$\begin{array}{c}\text { Radial } \\
\text { Runout } \\
\text { Max. }\end{array}$} & \multirow{2}{*}{$\begin{array}{l}\text { Width" } \\
\text { Variation } \\
\text { Max. }\end{array}$} & \multirow{2}{*}{$\begin{array}{c}\text { Outside Cylindrical } \\
\text { Surface Rưnout wtth } \\
\text { Reference Side } 3 \text { ) } \\
\text { Max. }\end{array}$} & \multirow{2}{*}{$\begin{array}{c}\text { Groove Runout } \\
\text { with Re ference } \\
\text { Side If } \\
\text { Max. }\end{array}$} \\
\hline Over & Incl. & Over & Incl. & $D_{\max }$ & $D_{m 1 n}$ & & & & \\
\hline $\begin{array}{r}0 \\
18 \\
30 \\
50 \\
80 \\
120 \\
150 \\
180 \\
250 \\
315\end{array}$ & $\begin{array}{r}18 \\
30 \\
50 \\
80 \\
120 \\
150 \\
180 \\
250 \\
315 \\
400\end{array}$ & $\begin{array}{r}0 \\
0.7087 \\
1.1811 \\
1.9685 \\
3.1496 \\
4.7244 \\
5.9055 \\
7.0866 \\
9.8425 \\
12.4015\end{array}$ & $\begin{array}{r}0.7087 \\
1.1811 \\
1.9685 \\
3.1496 \\
4.7244 \\
5.9055 \\
7.0866 \\
9.8425 \\
12.4015 \\
15.7480\end{array}$ & $\begin{array}{l}+0 \\
+0 \\
+0 \\
+0 \\
+0 \\
+0 \\
+0 \\
+0 \\
+0 \\
+0\end{array}$ & $\begin{array}{l}-1 \\
-1.5 \\
-1.5 \\
-1.5 \\
-2 \\
-2 \\
-2.5 \\
-3 \\
-3 \\
-4\end{array}$ & $\begin{array}{l}0.5 \\
1 \\
1 \\
1.5 \\
2 \\
2 \\
2 \\
2.5 \\
2.5 \\
3\end{array}$ & $\begin{array}{l}0.5 \\
0.5 \\
0.5 \\
0.5 \\
1 \\
1 \\
1 \\
1.5 \\
1.5 \\
2.5\end{array}$ & $\begin{array}{l}0.5 \\
0.5 \\
0.5 \\
0.5 \\
1 \\
1 \\
1 \\
1.5 \\
1.5 \\
2.5\end{array}$ & \begin{tabular}{|l}
0.5 \\
1 \\
1 \\
1.5 \\
2 \\
2 \\
2 \\
2.5 \\
2.5 \\
3
\end{tabular} \\
\hline
\end{tabular}

WIDIH TOLERANCE LIMITS

\begin{tabular}{|c|c|c|c|c|c|}
\hline \multicolumn{2}{|c|}{$\begin{array}{l}\text { BAEIC INNER } \\
\text { RING RORF } \\
\end{array}$} & \multicolumn{2}{|c|}{$\begin{array}{l}\text { BEARINOS OTHER THAN DUPLEX } \\
\text { WTDTH OF TNDTVTMIIAI. TNNFR OR OIITFR RTMG, }\end{array}$} & \multicolumn{2}{|c|}{$\begin{array}{l}\text { DUPLEX BEARINGS } \\
\text { TIT } \\
\text { TOTAL. WIDTH OF IMNER OR OUTER RIMSS }\end{array}$} \\
\hline \multicolumn{2}{|c|}{ MM } & \multicolumn{2}{|c|}{ WIDTH TOLERANCE LIMIIS } & \multicolumn{2}{|c|}{ WIDTH TOLERANCE LIMITS } \\
\hline Over & Incl. & High & Low & High & Low \\
\hline $\begin{array}{r}.0 \\
10 \\
18 \\
80 \\
180\end{array}$ & $\begin{array}{r}10 \\
18 \\
80 \\
180 \\
250\end{array}$ & $\begin{array}{l}+0 \\
+0 \\
+0 \\
+0 \\
+0\end{array}$ & $\begin{array}{r}-10 \\
-32 \\
-50 \\
-50 \\
-100\end{array}$ & $\begin{array}{l}+0 \\
+0 \\
+0 \\
+0 \\
+0\end{array}$ & $\begin{array}{l}-200 \\
-200 \\
-200 \\
-300 \\
-400\end{array}$ \\
\hline
\end{tabular}

1) Applies to groove type ball bearings only.

2) Outer Ring Tolerances apply before seals or shlelds are inserted.

3) Applies to Bearing Width Series 1, or narrower, as designated in AFBMA Standard Section No. 2 Boundary Dimensions.

4) If other than a pair of bearings is involved, the tolerance is in proportion to the number of bearings. 